\title{
CAMA
}

Centre for Applied Macroeconomic Analysis

\section{The Real Effects of Loan-to-Value Limits: Empirical Evidence from Korea}

\section{CAMA Working Paper 2/2020 January 2020}

\section{Victor Pontines}

The South East Asian Central Banks (SEACEN) Research and Training Centre Centre for Applied Macroeconomic Analysis, ANU

\section{Abstract}

This study adds to a recent and growing literature that assesses the effects of macroprudential policy. We compare the effects of monetary policy and loan-to-value ratio shocks for Korea, an inflation targeting economy and an active user of loan-to-value limits. We identify shocks using sign-restricted structural VARs and rely on a recent approach within this method to conduct structural inference. This study finds that both monetary policy and loan-to-value ratio shocks have effects on different measures of credit, i.e., real bank credit, real total credit and real household credit. We also find that both shocks have non-negligible effects on real house prices, including effects on real output, real consumption and real investment. We do, however, find that loan-to-value ratio shocks have negligible effects on the price level. These findings indicate that for the period covered by this study, limits on loan-to-value achieved their financial stability objectives in Korea in terms of limiting credit and house price appreciation under an inflation targeting regime. Furthermore, it attained these objectives without posing any threat to its price stability objective. Overall, these findings suggest that limits on loan-tovalue have important aggregate consequences despite it being a sectoral, targeted policy instrument. 


\section{Keywords}

Macroprudential Policy, Limits on Loan-to-Value, Monetary Policy, Sign Restrictions, Impulse Response, Forecast Error Variance Decomposition

\section{JEL Classification}

E31, E32, E52, E58, G28

\section{Address for correspondence:}

(E) cama.admin@anu.edu.au

\section{ISSN 2206-0332}

The Centre for Applied Macroeconomic Analysis in the Crawford School of Public Policy has been established to build strong links between professional macroeconomists. It provides a forum for quality macroeconomic research and discussion of policy issues between academia, government and the private sector.

The Crawford School of Public Policy is the Australian National University's public policy school, serving and influencing Australia, Asia and the Pacific through advanced policy research, graduate and executive education, and policy impact. 


\title{
The Real Effects of Loan-to-Value Limits: Empirical Evidence from Korea
}

By

\author{
Victor Pontines
}

\begin{abstract}
This study adds to a recent and growing literature that assesses the effects of macroprudential policy. We compare the effects of monetary policy and loan-to-value ratio shocks for Korea, an inflation targeting economy and an active user of loan-tovalue limits. We identify shocks using sign-restricted structural VARs and rely on a recent approach within this method to conduct structural inference. This study finds that both monetary policy and loan-to-value ratio shocks have effects on different measures of credit, i.e., real bank credit, real total credit and real household credit. We also find that both shocks have non-negligible effects on real house prices, including effects on real output, real consumption and real investment. We do, however, find that loan-to-value ratio shocks have negligible effects on the price level. These findings indicate that for the period covered by this study, limits on loan-to-value achieved their financial stability objectives in Korea in terms of limiting credit and house price appreciation under an inflation targeting regime. Furthermore, it attained these objectives without posing any threat to its price stability objective. Overall, these findings suggest that limits on loan-to-value have important aggregate consequences despite it being a sectoral, targeted policy instrument.
\end{abstract}

JEL Codes: E31, E32, E52, E58, G28

Keywords: Macroprudential Policy, Limits on Loan-to-Value, Monetary Policy, Sign Restrictions, Impulse Response, Forecast Error Variance Decomposition

Acknowledgments: The author would like to thank the participants of the High-Level Seminar for Directors of Research and Monetary Policy of SEACEN member central banks held on 4-5 July 2019 in Bali, Indonesia, and the conference on Macroeconomic Stabilization in the Digital Age jointly sponsored by the Sim Kee Boon Institute for Financial Economics, Singapore Management University (SMU) and the Asian Development Bank (ADB) Institute held on 1617 October 2019 in Singapore, where earlier versions of this study were presented. The author is also grateful to the comments and suggestions of Ole Rummel as well as to Seow Yun Yee for help in editing the manuscript.

* The South East Asian Central Banks (SEACEN) Research and Training Centre, Kuala Lumpur, Malaysia.

** Centre for Applied Macroeconomic Analysis (CAMA), Australian National University (ANU), Canberra, Australia.

Email: vicpontines@ hotmail.com

The views expressed herein are solely those of the author and do not necessarily reflect the views of CAMA-ANU, The SEACEN Centre and its member central banks. 


\section{Introduction}

One key lesson from the Global Financial Crisis that has altered how economic policymaking operates, particularly central banking, is the recognition that price and output stability do not ensure financial stability (Mishkin, 2012). Based on this message, macroprudential policies have become the standard toolkits with developed and developing countries alike implementing these instruments as policy responses to maintaining financial system stability. Given the growing experience in the use of these instruments, these policies can have a broad-based focus or they can be designed to target one or more sectors in the economy. ${ }^{1}$ Because these sectoral policy instruments are aimed at increasing the resilience of borrowers and lenders to shocks in income and asset prices (IMF-FSB-BIS, 2016), and thereby, constrain the level of expenditure in the targeted sector(s), they can also affect the level of output and prices in the economy. More importantly, if such effects are present, and, at the same time, because output and prices are considered traditional objectives of monetary policy (Richter et al., 2019), its implementation to "get into the cracks" needs to be appropriately adjusted than in the absence of these measures (IMF, 2013).

However, we still have limited empirical evidence as to whether these effects exist (Richter et al., 2019). ${ }^{2}$ The main contribution of the present study is to provide empirical evidence on the effects of loan-to-value limits (henceforth LTV), a wellknown sectoral policy instrument, on real output and the price level, including its effects on typical aggregate measures of financial imbalance, i.e., real credit and real house price. To achieve this purpose, we use the method of structural vector autoregression to identify LTV and monetary policy shocks for the Korean economy. ${ }^{3}$ Another contribution of this study is that we identify these shocks for this economy using the more modern technique of sign restrictions, and employ the recent innovation introduced by Inoue and Kilian (2013) to identify the structural shocks and conduct structural inference.

Korea is well-suited for such a study for a number of reasons. First, during the period covered by this study, Korea adopted an inflation targeting framework with a shortterm interest rate as its main instrument. Because we have a consistent and uniform

\footnotetext{
${ }^{1}$ A range of capital tools, including dynamic provisioning requirements, countercyclical capital buffer and time-varying leverage ratio caps are considered broad-based tools, while sectoral capital requirements, caps on foreign currency loans to corporates, limits on loan-to-value, debtservice-to-income ratio are some of the examples of these sectoral tools (IMF-FSB-BIS, 2016). 2 A recent study which addresses this limitation is by Richter, et al. (2019). This study specifically measures the effects of changes in the maximum loan-to-value ratio on output and inflation, among others, for a panel of 56 economies, both from advanced and emerging economies using quarterly data from 1990Q1 to 2012Q2.

${ }^{3}$ In this study, Korea refers to the Republic of Korea.
} 
monetary policy framework throughout our period of study, we can effectively rule out the possible effect of a heterogeneous monetary policy framework in the estimation results. This is particularly important as we may expect that the implementation of LTV limits may have, for instance, differing effects under an exchange rate-based monetary policy or when the central bank uses the reserve requirement as its main instrument instead of a short-term interest rate. ${ }^{4}$ Second, while it is an acknowledged inflation targeter, for part of the sample, it has also explicit financial stability objectives that are enshrined in the central bank's charter or statute (Kim and Mehrotra, 2018; Jeanneau, 2014). ${ }^{5}$ Because of this, it may then be worthwhile for this economy to understand whether a sectoral tool like LTV limits tasked with financial stability objectives of limiting excessive credit and house price appreciation, may also affect or interact with the traditional objectives of monetary policy (Richter et al., 2019). If so, this can then have an important bearing on its policy targets. Finally, among the countries in the world that have introduced LTV limits, Korea is one of the few that has had a longer history in its implementation. ${ }^{6}$

This study falls under a recent and growing strand of literature that assesses the effectiveness of macroprudential policies. However, a major weakness of almost all papers thus far in this literature is to use dummy variables to measure macroprudential policies. As pointed out by Richter et al., 2019, using dummy variables would not account for the intensity in the usage of the instrument. For instance, an LTV limit of 80 percent is treated equally to an LTV limit of 50 percent. In this study, we use the latest macroprudential database made available by a group of IMF staff (see Alam et al., 2019), which, to the best of my knowledge, makes available for the first-time countries' average numerical levels on LTV limits. ${ }^{7}$

We obtain the following findings. One of our baseline findings indicates that both shocks in monetary policy and LTV ratio have effects on real output, which were validated by several robustness tests. We also find, in one of our robustness tests, that both shocks have effects on real consumption and real investment. Our baseline results

\footnotetext{
${ }^{4}$ For similar arguments, see, for instance, Kim and Mehrotra (2018) and Glocker and Towbin (2015).

${ }^{5}$ Under the Bank of Korea Act, which took effect in 2011, the country's central bank was also provided a mandate to pursue financial stability objectives. See, for instance, the discussion in Shin, Lee and Park (2017).

${ }^{6}$ Jung and Lee (2017) provide the dates of the introduction by countries of limits on LTV based on IMF data. According to this study, there are only three other countries that have a longer history than Korea in the implementation of such limits, namely, Hong Kong (1991), Singapore (1996) and Colombia (1999). Korea introduced theirs in 2002.

${ }^{7}$ Richter et al., (2019) is another study which veers away from the use of dummy variables. In their study, to quantify the effects of LTV limits, they extended the database for policy actions on housing markets constructed by Shim et al., (2013), and then use the changes in the maximum LTV ratios.
} 
indicate though that LTV ratio shocks have negligible effects on the price level. This finding is mainly supported by a battery of robustness tests. We also obtain evidence that both monetary policy and LTV ratio shocks have effects on real bank credit, which were found to be robust to alternative measures of credit such as real total credit and real household credit. Finally, both shocks also have non-negligible effects on real house prices, evidence that were also confirmed by our extensive robustness tests.

The paper is structured as follows. The next section provides a literature survey of some of the studies relevant to this study. The third section presents some stylized trends on the average LTV limits in Korea. The fourth section provides a discussion of the empirical method employed in this study. The fifth section discusses the data. The sixth section discusses the baseline empirical results, including the battery of robustness tests conducted. The final section concludes.

\section{Literature Review}

There is a dearth of studies that examine the aggregate effects of macroprudential policies on output and the price level let alone a sectoral policy tool such as LTV limits. Kim and Mehrotra (2018) examined the effects of monetary and macroprudential policies on real GDP, the price level, real credit growth and real house price in four inflation targeting economies in the Asia-Pacific region using a recursive VAR. They found that tight macroprudential policies contain credit growth, and also significantly reduce output and the price level. Two studies that employed numerical data on LTV limits and thus, are more closely related to this study are by Richter et al., (2019), and Alam et al., (2019). Richter et al., (2019) uses panel data comprising of 56 economies, including advanced and emerging market economies to specifically investigate the effects of numerical changes in maximum LTV ratio on real output, inflation, credit and house price growth from 1990Q1 to 2012Q2 using a narrative identification procedure. They found that changes in maximum LTV ratios appear to have relatively modest effects on output and inflation. After employing a number of different specifications and robustness tests, the effects of LTV changes on inflation tend to be negligible. They also found that LTV changes have substantial effects on credit growth and house price growth. Alam et al., (2019) uses their numerical data on the average LTV limits for 66 economies and found that LTV tightening has a strong effect on household credit.

This study is also related to a recent and growing literature that examined the link between macroprudential policies and financial stability. The discussion that follows does not intend to provide an exhaustive survey of the literature as this has been done elsewhere (see, for instance, the excellent surveys of the literature by Galati and 
Moessner, 2018; Cerutti et al., 2017; and, Carreras et al., 2018). Our intention then in this section is to cite some of the recent studies that were not included in these three important literature surveys. Taken together, the empirical evidence appears to indicate that macroprudential policies have an effect on credit and asset prices.

Greenwood-Nimmo and Tarassow (2016) examined the effects of macroprudential shocks on aggregate financial fragility using a sign-restricted VAR for the US from 1960Q1 to 2007Q4. The authors found that when interest rates are fixed, creditconstraining macroprudential shocks may be able to reduce the credit-to-GDP ratio in the short-run but are unable to reduce the financial ratio (ratio of firms' debts to their internal funds). However, when the interest rate is free to accommodate the macroprudential shock, both the credit-to-GDP ratio and the financial ratio decline, indicating a reduction in financial fragility. Fendoglu (2017), based on a panel of 18 emerging market economies for the period 2000Q1 to 2013Q2, found that borrowerbased measures with a domestic focus, and domestic reserve requirements are significant in smoothing credit cycles, while weaker results were found for FX-related measures. Morgan et al., (2019) specifically examined the effectiveness of LTV ratios on mortgage lending moderation using a sample of more than 4,000 banks from 46 countries. They found that mortgage loans were successfully curbed in countries with an LTV policy.

There are recent studies that use Korea as a country study to assess the effects of LTV ratios on credit and asset price. Jung et al., (2017) found that it has significant and persistent effects on real household credit and real house price in a recursive VAR for the period 2000Q1 to 2015Q4. Tillmann (2015) using a Qual VAR also found that a tightening in LTV limits is effective in dampening credit growth and reducing the appreciation of house prices for the period 2000Q1 to 2012Q4. Evidence from an event study using monthly house price transactions data for a panel of 73 districts in Korea from 2006-2015, Jung and Lee (2017) found that LTV limits are useful but are not robust in curbing excessive household debt.

\section{Some Stylized Trends on the Average LTV Limits in Korea}

The implementation of macroprudential policies in Korea is a shared responsibility between the central bank and its financial supervision agencies, the latter of which are comprised of the following agencies: (i) the Ministry of Strategy and Finance (MOSF), which is responsible for the formulation, overall control and adjustment of economic and fiscal policies, (ii) the Financial Services Commission (FSC), which formulates the financial policies, including the policies and regulations for supervision, (iii) the Financial Supervisory Service (FSS), which carries out the financial supervision 
pursuant to rules and regulations set by the FSC (FSB, 2017; Shin, Lee and Park, 2017). ${ }^{8}$ Similar to the implementation of other important macroprudential instruments in Korea, LTV limits have been adjusted in a broadly countercyclical manner, tightened or relaxed as warranted by cyclical developments in housing markets and bank lending (Kim, 2014). Figure 1 shows the tightening and loosening episodes based on average LTV limits in Korea since the time it pursued an inflation targeting regime in the early 2000s until end-2016. The figure indicates that there were two tightening episodes (2002Q3 - 2003Q4 and 2005Q3 - 2008Q3) and there were also two episodes of loosening on LTV limits (2004Q1 - 2005Q2 and 2008Q4 and 2014Q4).

\section{INSERT FIGURE 1 HERE}

According to anecdotal evidence, the first tightening episode was triggered by a motivation to curb financing for speculative purposes, which saw real estate prices rise in the so-called speculative zones (Lee, 2013). ${ }^{9}$ This led to the introduction of a 60 percent LTV limit in the third quarter of 2002, which was immediately applied to all loans for house purchases in speculative zones and other areas. Then in the second and last quarter of 2003, the LTV limits were further reduced to 50 percent for loans of 3 years maturity and less and 40 percent for loans of 10 years maturity and less, respectively (Alam et al., 2019). These restrictions contributed to an average LTV limit of 63 percent during this period from a high of 90 percent.

Following the first tightening episode, there was a brief loosening episode that started from 2004Q1 and lasted until 2005Q2. The major relaxation during this time was when the LTV limit on loans with 10 years maturity or more increased from 60 percent to 70 percent in the first quarter of 2004 (Lee, 2013). The second tightening episode that spanned the period from 2005Q3 to 2008Q3 saw LTV limits expand their application to the non-bank financial institutions as well as an enlarged number of designated speculative zones covered by the LTV limit $^{10}$ (Igan and Kang, 2011; Jung and Lee, 2017). The average LTV limit during this period was around 54 percent.

While the LTV limit was expanded to all financial institutions located in the metropolitan areas, during the period that followed from 2008Q4 to 2014Q4, in the midst of the Global Financial Crisis, the supervisory authorities in an effort to revitalize

\footnotetext{
${ }^{8}$ There is also the Korea Deposit Insurance Corporation (KDIC) but this agency is primarily responsible for managing and operating the deposit insurance funds and resolving ailing institutions.

${ }^{9}$ These designated speculative zones or areas tend to change over time but for most times cover Seoul and its surrounding metropolitan areas.

10 The area of Gangbuk in Seoul and the neighbouring area of Incheon were also designated as speculative zones during this period.
} 
the housing market moved toward relaxing restrictions and lifting LTV limits. For instance, in the last quarter of 2008, it removed all areas designated as speculative zones, except for three up-market areas in Seoul. ${ }^{11}$ By the second quarter of 2012, however, these three remaining areas were excluded from the list of speculative zones, which led to the complete elimination of such designated areas. Also, in the direction of a loose LTV policy, in the third quarter of 2014, a uniform LTV limit of 70 percent was applied to the Seoul metropolitan area for the banking sector, and an LTV limit of between 65 percent to 85 percent for the non-bank financial institutions. This brought the average LTV limit during this period to 62 percent. Beyond this period, by end of 2016, the average LTV limit in Korea stood at 77 percent (Alam et al., 2019).

\section{Empirical Methodology}

Section 4.1 discusses the VAR model specification and the use of sign-restricted VARs in this study. Section 4.2 presents our identifying sign-restrictions. Section 4.3 describes our adopted technique in terms of characterizing the central tendency of the structural impulse response functions in a sign-restricted VAR.

\subsection{VAR specification and sign-restricted VARs}

A $p$ th order reduced form VAR model is estimated. In vector notation, this can be expressed as:

$$
\mathbf{y}_{\mathbf{t}}=\mathbf{c}+\sum_{i=1}^{p} \mathrm{~A}_{\mathrm{i}} \mathbf{y}_{\mathbf{t}-\mathbf{i}}+\mathbf{e}_{\mathbf{t}}
$$

where $\mathbf{y}_{\mathbf{t}}$ is a $k \times 1$ vector containing the endogenous variables observed over the period $\mathbf{t}=1,2, \ldots, T, \mathbf{c}$ is a vector of constant terms, the $\mathrm{A}_{\mathrm{i}}$ 's are $k \times k$ matrices of autoregressive coefficients, $\mathbf{e}_{\mathbf{t}}$ are the reduced-form innovations with zero mean and positive definite covariance matrix, $\Sigma_{\mathrm{e}}$. Along with the following variables, namely, the log of real GDP $\left(\operatorname{rgdp}_{\mathrm{t}}\right)$; the log of the price level ( price $\left._{\mathrm{t}}\right)$; the interest rate (intrate $)_{\mathrm{t}}$ ); and, the limits on LTV $\left(\operatorname{ltv}_{\mathrm{t}}\right)$, two different baseline specifications of equation (1) are estimated, one in which the log of real bank credit (rbcredit $t_{t}$ ) is included as one of the endogenous variables, and the other where the log of real house price (rhsprice t $_{t}$ is included rather than rbcredit. These variables are contained in the vector $\mathbf{y}_{\mathbf{t}}{ }^{12}$ In the baseline estimations, we follow the conventional approach of specifying a normal-inverse Wishart prior distribution for the coefficient matrices and the covariance matrix (e.g., Uhlig, 2005), and select a lag length of two according to the Final Prediction error (FPE) and the Hannan-Quinn (HQ) information criterion.

11 These three areas were Seocho, Gangnam and Songpa.

${ }^{12}$ We follow the large body of literature that determines the effects of monetary policy by including all variables in levels (e.g., Christiano et al., 1999). 
However, to disentangle cause and effect, we are not directly interested in the reducedform innovations contained in $\mathbf{e}_{\mathbf{t}}$, which requires us instead to use the structural form given as follows:

$$
B_{0} \mathbf{y}_{\mathbf{t}}=\mathbf{k}+\sum_{i=1}^{p} B_{\mathbf{i}} \mathbf{y}_{\mathbf{t}-\mathbf{i}}+\boldsymbol{\varepsilon}_{\mathbf{t}}
$$

where $B_{0}$ is a $k \times k$ matrix containing the contemporaneous responses of the variables to the structural shocks, the $B_{\mathrm{i}}$ 's are the $k \times k$ matrices of structural coefficients, and $\boldsymbol{\varepsilon}_{\mathrm{t}}$ is the $k \times 1$ vector of structural shocks with a covariance matrix that is typically normalized $E\left[\boldsymbol{\varepsilon}_{\mathbf{t}} \boldsymbol{\varepsilon}_{\mathbf{t}}^{\prime}\right]=\Sigma_{\varepsilon}=I_{k}$. By construction, $\mathbf{e}_{\mathbf{t}}=B_{0}^{-1} \boldsymbol{\varepsilon}_{\mathbf{t}}$, that is, the reduced-form innovations $\mathbf{e}_{\mathbf{t}}$ are a weighted average of the structural shocks $\boldsymbol{\varepsilon}_{\mathbf{t}}$. Hence, the relation between the reduced-form VAR innovations and the structural shocks is $\Sigma_{\mathrm{e}}=B_{0}^{-1} B_{0}^{-1 \prime}$. With no additional information or assumptions, however, $B_{0}$ or its inverse is unidentified. Restrictions on $B_{0}$ are necessary to achieve identification. ${ }^{13}$ The traditional approach in restricting $B_{0}$ is to invoke strong assumptions such as recursive and zero exclusion restrictions following Sims (1980), Blanchard and Watson (1986). However, as highlighted in the literature, there is scepticism with this common approach because evidence of a price puzzle is often found when using this identification scheme (Sims, 1992, 1998; Zha, 1997, Christiano et al., 1999).

Following the work of Faust (1998), Canova and de Nicoló (2002, 2003) and Uhlig (2005), sign-restrictions provide an alternative way to do structural inference in VARs. This alternative method of identifying policy shocks in VARs works by restricting the sign of the responses of selected macroeconomic variables to policy shocks (Inoue and Kilian, 2013). For instance, using US data, Uhlig (2005) assumed that an unexpected monetary policy contraction is associated with an increase in the federal funds rate, the absence of price increases and the absence of increases in nonborrowed reserves for six months following the policy shock. The increased popularity in the use ${ }^{14}$ of this alternative identification scheme can be due to being generally weaker than the traditional identifying restriction because it is based on inequality constraints as well as being invariant to the ordering of the variables in the system (Greenwood-Nimmo and Tarassow, 2016).

\footnotetext{
${ }^{13}$ Also referred to in the VAR literature as identifying assumptions or restrictions.

${ }^{14}$ For instance, Canova and Pappa (2007), Mountford and Uhlig (2009), Pappa (2009), Caldara and Kamps (2017) use sign-restricted VARs to study fiscal policy shocks; Dedola and Neri (2007) and Peersman and Straub (2009) also used sign-restricted VARs to study technology shocks; and, sign-restricted VARs were used by Baumeister and Peersman (2013), Kilian and Lee (2014), Kilian and Murphy $(2012,2014)$ and Lippi and Nobili (2012) to study oil price shocks.
} 
Sign-restricted VARs proceed by first defining $\varepsilon_{\mathrm{t}}^{*}=P Q$ where matrix $P$ is the lowertriangular Cholesky decomposition of $\Sigma_{\mathrm{e}}$, such that $P P^{\prime}=\Sigma_{\mathrm{e}}$, and matrix $Q$ is a $k \times k$ orthonormal matrix with $Q Q^{\prime}=Q^{\prime} Q=I_{k}$. The decomposition of $\Sigma_{\mathrm{e}}$ can be rewritten as $\Sigma_{\mathrm{e}}=P Q Q^{\prime} P^{\prime} . Q$ is obtained by drawing from a uniform $[0, \pi]$ distribution in line with Uhlig (2005). Because $Q$ is orthogonal, multiplying uncorrelated structural shocks with $Q$ yields structural shocks that are uncorrelated, but with different impulse response functions. If the responses of the variables to the shocks satisfy the sign restrictions for the corresponding length or horizon of the restrictions, the responses are kept, otherwise they are discarded. This process is repeated until a certain number of responses are accepted. This then highlights that, unlike traditional recursive VARs, sign-restricted VARs are no longer point identified, but are set identified.

\subsection{Identifying restrictions}

Since we consider a VAR model with five variables, there are five structural shocks. We identify four structural shocks in our model, namely, aggregate demand (AD) shock, aggregate supply (AS) shock, monetary policy (MP) shock, and a LTV ratio shock, while the fifth structural shock is a residual shock designed to capture all other shocks driven by a number of reasons that cannot be classified as one of the first four structural shocks. Tables 1.A and 1.B summarize the corresponding identifying sign restrictions that we impose in this study. While there is no difference in the imposed sign restrictions between the two panels in Table 1, Table 1.A includes the log of real bank credit ( rbcredit $_{\mathrm{t}}$ ) as one of the endogenous variables in the baseline VAR specification while in Table 1.B, the $\log$ of real house price (rhsprice $)_{t}$ ) is included instead of rbcredit. Although, there is no definitive guidance provided in the literature on sign-restricted VARs, we follow Uhlig (2005) in using a dynamic horizon of two quarters, i.e., the quarter of impact and the following, for the identifying sign restrictions.

\section{INSERT TABLES 1.A AND 1.B HERE}

In an aggregate demand shock, output and prices move in the same direction. The central bank responds to a positive aggregate demand shock by lowering the interest rate. A negative aggregate supply shock has a non-positive effect on output and a nonnegative effect on prices. The central bank reacts to an adverse aggregate supply shock by increasing the interest rate. In the VAR literature, similar restrictions both for aggregate demand and supply shocks were employed by Peersman (2005), Hristov et 
al., (2012), while Straub and Peersman (2006), Canova and Paustian (2011) provided the evidence from DSGE models. ${ }^{15}$

A contractionary monetary policy shock does not lead to a decrease in the interest rate, and does not lead to increases in output, prices, bank credit (Table 1.A) and house prices (Table 1.B). The imposed restrictions on output and prices are consistent with the voluminous literature that examined the effects of monetary policy shocks on both variables with the imposed restriction on prices, with the price puzzle avoided by construction (e.g., Greenwood-Nimmo and Tarassow, 2016; Eickmeier et al., 2009; Duchi and Elbourne, 2016; Bijsterbosch and Falagiarda, 2015; Finlay and Jääskelä, 2014; Peersman, 2005; Hristov et al., 2012; while, Straub and Peersman, 2006; Canova and Paustian, 2011 provided the evidence from DSGE models). The imposed restriction on credit is in line with evidence from DSGE models (e.g., Alpanda and Zubairy, 2017 and 't Veld et al., 2014). The imposed restriction on house prices is consistent with evidence from VAR-based studies such as Del Negro and Otrok (2007), Goodhart and Hofmann (2008), Jarociński and Smets (2008), Sá, Towbin and Wieladek (2014) as well as the imposed sign restriction in the study of Ume (2018).

In a loose LTV ratio shock, output, bank credit (Table 1.A), and house prices (Table 1.B) respond in the same direction. These restrictions are in line with evidence from the DSGE models of Alpanda and Zubairy, 2017 and 't Veld et al., 2014. We are mainly interested in the comparison of the two latter shocks (i.e., monetary and LTV ratio shocks), which will be the focus of our discussion in subsequent sections.

\subsection{The modal model and credible sets of Inoue and Kilian (2013)}

As mentioned, because sign-restricted VARs are set identified, the standard approach in the literature is to report the vector of pointwise posterior medians of the impulse responses, or simply, median impulse responses, which involves ordering the accepted impulse responses at each horizon into ascending order and selecting the $50^{\text {th }}$ percentile impulse response. As pointed out by Kilian and Inoue (2013) and Kilian and Lütkepohl (2017), this approach suffers from two distinct shortcomings. One is that the median impulse responses lack a structural economic interpretation because these responses will not correspond to the response function of any of the accepted set of models, unless the pointwise posterior medians of all impulse response coefficients in the VAR correspond to the same structural model, which is unlikely a priori (see also, for instance, Fry and Pagan, 2011; Kilian and Murphy, 2012). The other shortcoming is that median impulse responses are not a valid statistical summary of the central

15 Some other VAR-based studies have left unrestricted the response of the central bank to an aggregate supply shock. For example, Eickmeier et al., (2009), Duchi and Elbourne (2016), Bijsterbosch and Falagiarda (2015), Finlay and Jääskelä (2014). 
tendency of the accepted set of impulse response functions because the vector of medians is not the median of a vector valued random variable. Because of this second limitation, there is then no compelling reason to focus on the posterior median response functions.

Inoue and Kilian (2013) proposed a solution to these two problems. They showed that the most likely structural model from the accepted set of models can be determined by computing the posterior mode of the joint distribution of the accepted set of models. By doing so, their proposal moves away from using the posterior median in favour of the posterior mode of the joint distribution of the accepted set of models. With the objective of ranking the structural models in the accepted set of models, the latter is obtained as follows. ${ }^{16}$ Let $A=\left[A_{1}, \ldots, A_{p}\right]$ be the $k$-variate reduced form VAR coefficients, $P$ is the lower-triangular Cholesky decomposition of $\Sigma_{\mathrm{e}}$, and let $\operatorname{vech}(P)$ denote the $k(k+1) / 2 \times 1$ vector that consists of the on-diagonal elements and the belowdiagonal-elements of $P$. Then, $\mathrm{S}=I_{k}-2\left(I_{k}+Q\right)^{-1}$ is a $k \times k$ skew-symmetric matrix, where $Q$ is the $k \times k$ orthogonal matrix and its determinant is $|Q|=1$. From here, let $\mathbf{s}$ denote the $k(k-1) / 2 \times 1$ vector that consists of the above diagonal elements of $\mathrm{S}$. The density of $\mathbf{s}$ is given by:

$$
f(\mathbf{s})=\left(\prod_{i=2}^{k} \frac{\Gamma\left(\frac{i}{2}\right)}{\pi^{i / 2}}\right) \frac{2^{(k-1)(k-2) / 2}}{\left|I_{k}+S\right|^{k-1}}
$$

where $\Gamma(x) \equiv \int_{0}^{\infty} z^{x-1} e^{-z} d z$ and $|$.$| denotes the determinant.$

From the joint posterior density of $(\operatorname{vec}(A), \operatorname{vech}(P), \mathbf{s})$, where $\Theta$ is the known nonlinear function $\Theta=h(\operatorname{vec}(A), \operatorname{vech}(P), \mathbf{s})$, the posterior density $f(\Theta)$ can be written in closed form as:

$$
f(\Theta) \propto\left|\frac{\partial \operatorname{vec}(\Theta)}{\partial\left[\operatorname{vec}(A)^{\prime}, \operatorname{vech}(P)^{\prime}, \mathbf{s}^{\prime}\right]}\right|^{-1}\left|\frac{\partial \operatorname{vech}\left(\Sigma_{e}\right)}{\partial \operatorname{vech}(P)^{\prime}}\right| f\left(A \mid\left(\Sigma_{e}\right) f\left(\Sigma_{e}\right) f(\mathbf{s})\right.
$$

This formula is used to compute the numerical value of the posterior density for every possible draw of the structural model $\left(\Theta^{r}\right)^{17}$. Letting $\Omega$ denote the accepted set of models, to obtain the most likely structural model from $\Omega$, Inoue and Kilian (2013) proposed that this modal structural model is the model that maximizes the value of $f(\Theta)$ in equation (4) among all the accepted set of models $(\Omega)$.

Furthermore, as likewise pointed out by Inoue and Kilian (2013) and Kilian and Lütkepohl (2017), it is common in practice to connect the upper quantiles for a given

\footnotetext{
16 The succeeding discussion on obtaining the posterior mode of the joint distribution of the accepted set of models draws from Kilian and Lütkepohl (2017).

${ }^{17}$ The superscript letter $r$ stands for a particular random draw.
} 
impulse response function to form an upper band, and similarly to connect the lower quantiles to form a lower band. As also earlier highlighted by Sims and Zha (1999), these error bands do not account for the dependence of the structural impulse responses across horizons and across response functions. In this regard, Inoue and Kilian (2013) correspondingly proposed a highest posterior density (HPD) credible set that characterizes the joint uncertainty about the accepted set of models. They defined the corresponding $(1-\gamma) 100 \%$ HPD credible set as:

$$
\mathcal{S}=\left\{\Theta \in \Omega \mid f(\Theta) \geq c_{\gamma}\right\}
$$

where $c_{\gamma}$ is the largest constant such that $\mathbb{P}(\mathcal{S}) \geq 1-\gamma$ is the credible set.

In summary, to implement a Bayesian method to sign-restricted VAR, and using the Inoue and Kilian (2013) technique to characterize the central tendency of the structural impulse response functions, we proceed as follows: ${ }^{18}$ One, we take a random draw $\left(A^{r}\right.$, $\left.P^{\prime}\right)$ from the posterior of the reduced-form VAR parameters. Two, for $\left(A^{r}, P^{\prime}\right)$, consider $N$ random draws of the rotation matrix $Q$ such that for each combination $\left(A^{r}, P^{r}, Q\right)$ compute the set of the implied structural impulse responses, $\Theta^{\mathrm{r}}$. Three, if $\Theta^{\mathrm{r}}$ satisfies the sign restrictions, compute $f\left(\Theta^{r}\right)$, and keep $\Theta^{r}$ and $f\left(\Theta^{r}\right)$. Otherwise discard both. Four, repeat steps one, two and three $M$ times. Sort the pairs $\left\{\Theta^{\mathrm{r}}, f\left(\Theta^{\mathrm{r}}\right)\right\}$ that satisfy the sign restrictions in descending order by the value of $f\left(\Theta^{r}\right)$. Then the $\Theta^{r}$ in the first sorted pair is the most likely structural model (i.e., modal model) and the $(1-\gamma) 100 \%$ HPD credible set is obtained by selecting the set of $\Theta^{\mathrm{r}}$ contained in the first $(1-\gamma) 100 \%$ sorted pairs. In this study, to construct the posterior distribution of the impulse responses, we follow Inoue and Kilian (2013) and the use of $M=5,000$ draws from the reduced-form posterior distribution with $N=20,000$ rotations each. We also set $\gamma$ equal to 0.32 such that we obtain the 68 percent joint HPD region. ${ }^{19}$

As noted by Inoue and Kilian (2013), because the elements of the HPD credible sets differ from conventional error bands for impulse responses in that the elements of the credible sets are vectors representing the impulse response functions up to some prespecified horizon, the plot of the credible sets will typically exhibit a shot-gun pattern. Finally, once the modal structural model is found, we base on it a

\footnotetext{
18 This also follows from Kilian and Lütkepohl (2017).

19 In implementing equations (3), (4) and (5) above to characterize the central tendency of the structural impulse response functions in a sign-restricted VAR according to Inoue and Kilian (2013), we use the original codes provided by Lutz Kilian in his website at: https://sites.google.com/site/lkilian2019/research/code. The original codes use both sign and magnitude restrictions to study the global oil market in a three-variable VAR. Portions of the codes were modified to implement a pure sign restrictions approach for this study. We gratefully acknowledge him for making the original codes available.
} 
straightforward extension of a further calculation, for instance, the forecast error variance decomposition.

\section{Data}

The data frequency is quarterly and the period of examination is from 2001Q1 to 2016Q4 ${ }^{20}$ The reason the sample period starts at the beginning of 2001 is because the adoption of an inflation targeting regime in Korea is officially acknowledged to have commenced at this time (see, for instance, Fouejieu, 2017) ${ }^{21}$ and as such, we want to maintain a consistent monetary policy regime in our estimations. ${ }^{22}$ The reason that the sample period ends at the end-2016 is because our data on LTV limits are unavailable past this point of time. The variables of interest in our baseline estimations are as follows: Real GDP, price level, interest rate, LTV limits, real bank credit and real house price. We also considered in our robustness tests, data on alternative measures of credit, namely, real total credit and real household credit, as well as two components of GDP, real consumption and real investment.

Data on Korea's LTV limits were obtained from the latest macroprudential database made available by a group of IMF staff (see Alam et al., 2019). To the best of my knowledge, this is the first ever macroprudential database that provides average numerical levels on LTV limits across countries as opposed to previous macroprudential databases that provide only dummy-type policy action indicators. ${ }^{23}$ The average levels of LTV limits, which were recorded based on dates of effectivity rather than on announcement dates (Alam et al., 2019), are available from 2000Q1 to 2016Q4. The data on the different measures of credit, house prices and interest rates were gathered from the credit, property prices, and policy interest rates statistics website, respectively, of the Bank for International Statistics (BIS). The rest of the data were obtained from the International Financial Statistics (IFS) database of the International Monetary Fund (IMF).

\section{Empirical Results}

\footnotetext{
20 Using also quarterly data, this is almost the same period covered by Tillmann (2015) and Jung et al. (2017). See the discussion in section II above.

${ }^{21}$ In contrast, Ardakani et al., (2018) posit a different start date of 1998Q2.

22 For a similar strategy, see, for instance, Kim and Mehrotra (2018).

${ }^{23}$ See Appendix I Table 4 of Alam et al., (2019) which provide a comprehensive comparison of their database to other existing databases on macroprudential policies.
} 
Given our two baseline specifications, this section presents the impulse responses following the suggestion of Inoue and Kilian (2013) to determine the modal model, and the forecast error variance decomposition which is based on this modal model. Subsection 6.1 presents these results when the real bank credit is included as one of the endogenous variables in our baseline VAR, while sub-section 6.2 presents the results when the real house price is included instead.

\subsection{Baseline results: VAR specification that includes real bank credit}

\subsubsection{Impulse responses}

Because this study is mainly interested in the comparison of a monetary policy shock to a LTV ratio shock, Figure 2 displays the impulse responses of each variable to a contractionary monetary policy shock (first column) and a loose LTV ratio shock (second column) in the modal model (solid line) along with the corresponding 68 percent credible sets (shaded area) over a horizon of 20 quarters. ${ }^{24}$

\section{INSERT FIGURE 2 HERE}

In regard to the monetary policy shock, the policy rate (third row) reacts positively, rising on impact by 5 basis points, then quickly reversing course within the next two quarters. After this, the policy rate oscillates between negative and positive territories, and then eventually converges to zero. Real GDP (first row) reacts negatively to a contractionary monetary policy shock on impact, and the responses remaining negative for the next five quarters. After this, real GDP gradually converges to zero after the initial shock. The price level's response (second row) is persistently negative but sluggishly dropping by about 0.15 percent within a year, and falling by only almost 0.2 percent within five years. The real bank credit's response (fourth row) is swift and large, dropping by 2.5 percent on impact. The reduction persists for the first 10 quarters before finally almost converging to zero thereafter. Lastly, the LTV limit (fifth row) reacts somewhat positively on impact to a contractionary monetary policy shock. However, for the rest of the periods, there is very little response from the LTV limit to the monetary policy shock. The combination of the shot-gun pattern and the absence of pointwise probability mass of both positive and negative responses in most of the endogenous variables suggest that the corresponding credible sets of the response functions of real GDP, the price level, the policy rate and the real bank credit are precisely enough estimated to be of economic significance, at least for the first two quarters.

\footnotetext{
${ }^{24}$ The impulse responses of the remaining structural shocks are available upon request.
} 
In regard to the LTV ratio shock, the LTV limit in response to a loose LTV ratio shock, reacts positively on impact. This rise in the LTV limit is quite persistent, converging only to zero closer to the end of the impulse response horizon. There is a hump-shaped response of real GDP with a positive effect on impact, and a peak response of about 1 percent in the second quarter. After this quarter, the responses oscillate between negative and positive territories after which it then eventually converges to zero. Interestingly, the responses of real bank credit are similar to those of the responses of real GDP with a positive effect on impact and reaches its peak response in the second quarter (about 1.5 percent). Beyond this quarter, it also gradually converges to zero. As to the responses of the price level, there is little response to a LTV ratio shock over the entire horizon of 20 quarters. A similar observation also applies to the responses of the policy rate to a LTV ratio shock. With regard to the corresponding credible sets, the combination of the shot-gun pattern and the absence of pointwise probability mass of both positive and negative responses in most of the endogenous variables, the response functions of real GDP, real bank credit, and the LTV limit, are likewise precisely enough estimated to be of economic significance, at least for the first two quarters.

\subsubsection{Variance decomposition}

Next, to understand the quantitative importance of the structural shocks to the three variables of interest, i.e., real GDP, the price level and real bank credit, we compute the forecast error variance decomposition based on the modal model. Table 2 reports the forecast error variance decomposition of the three variables at the 1 to 5 -year forecast horizon. The final column shows that the identified structural shocks explain a large part, at least two-thirds, of the variations in the three variables. Both aggregate demand and aggregate supply shocks account for the bulk of the variations in real GDP. The monetary policy shock explains a large portion of the variations in the price level (along with aggregate supply shock) and real bank credit (along with the aggregate demand shock).

\section{INSERT TABLE 2 HERE}

With an average share of about 7 percent, the contribution of the LTV ratio shock to the fluctuations in real GDP is almost as high as that of a monetary policy shock. Furthermore, the LTV ratio shock accounts for about 13 percent (similar to aggregate demand shock) of the variations in the price level, while it accounts for about 8 percent (larger than aggregate demand shock) of the variations in real bank credit.

\subsection{Baseline results: VAR specification that includes real house price}

\subsubsection{Impulse responses}


Again over a horizon of 20 quarters, Figure 3 displays the impulse responses of each variable to a contractionary monetary policy shock (first column) and a loose LTV ratio shock (second column) in the modal model (solid line) along with the corresponding 68 percent credible sets (shaded area) for the VAR specification that includes the real house price rather than real bank credit. ${ }^{25}$

\section{INSERT FIGURE 3 HERE}

The responses of real GDP, the price level, and the policy rate to a monetary policy shock in Figure 3 are very similar to the ones we obtained for these set of variables in our first baseline specification above (Figure 2, first column). The policy rate also reacts positively (rising by about 6 basis points), then quickly reverses course within the next two to three quarters. Real GDP reacts negatively on impact, and the responses remaining negative for the next two quarters. Beyond this period, real GDP oscillates between positive and negative territories before converging to zero. The price level's response is again persistently negative but sluggishly dropping by about 0.18 percent within a year, and falling by only almost 0.16 percent within five years.

Real house price has a negative hump-shaped response to a contractionary monetary policy shock, reaching its negative peak response after about three quarters. The responses remain negative for another four quarters before finally converging to zero. This time, the LTV limit reacts negatively on impact to a contractionary monetary policy shock after which it gradually converges to zero. Again, similar to Figure 2, the corresponding credible sets indicate that the response functions of the price level and the policy rate are precisely enough estimated for the first two quarters, while in the case of real GDP, at least for the first three quarters. The more notable finding, however, is the response function of real house prices which based on its corresponding credible sets is precisely estimated at horizons more than two quarters, i.e., about five quarters.

In regard to the LTV ratio shock, the responses of the price level, the policy rate and the LTV limit to a loose LTV ratio shock are quite similar to the ones we obtained in our first baseline specification (Figure 2, second column). The LTV limit in response to a loose LTV ratio shock, reacts positively on impact. The price level reacts very little, and the same observation applies to the responses of the policy rate. Real GDP, on the other hand, reacts to the LTV ratio shock positively on impact and the responses remain positive for the next two quarters. Beyond this period, it drops below zero, oscillates between negative and positive territories until it converges to zero. Real house price has a hump-shaped response to a LTV ratio shock with a positive response

\footnotetext{
${ }^{25}$ The impulse responses of the remaining structural shocks are again available upon request.
} 
on impact and reaching its peak response in the second quarter. The responses remain positive for another five quarters before they converge to zero. Finally, the corresponding credible sets indicate that the response functions of real GDP and the LTV limit are precisely enough estimated for the first two quarters, whereas the response function of real house price is precisely estimated for the first three quarters.

\subsubsection{Variance decomposition}

To understand the quantitative importance of the structural shocks to real GDP, the price level and real bank credit, the forecast error variance decomposition based on the modal model is computed. Table 3 reports the forecast error variance decomposition of the three variables at the 1 to 5 -year forecast horizon for the VAR specification that includes the real house price instead of real bank credit. Again, the final column shows that the identified structural shocks explain almost all of the variations in the three variables. Both aggregate demand and aggregate supply shocks not only account for the bulk of the variations in real GDP, but also the variations in the price level.

\section{INSERT TABLE 3 HERE}

With a share on average of about 12 percent over the five-year horizon, the contribution of the LTV ratio shock to the variations in real GDP is large. Moreover, although not as high as the contribution of the monetary policy shock (about 22 percent), the LTV ratio shock accounts for about 11 percent of the fluctuations in the price level. Finally, interestingly, both the LTV ratio and monetary policy shocks account for the bulk of the fluctuations in real house price.

\section{Robustness tests}

In this section we examine the extent to which our two previous baseline results are sensitive to different measures of credit, real consumption or real investment as one of the endogenous variables in the VAR instead of real GDP with the price level replaced by inflation as the endogenous variable, and the consideration of an alternative sign identification restriction. In terms of the impulse responses, we again present the responses of each variable to a contractionary monetary policy shock (first column) and a loose LTV ratio shock (second column). ${ }^{26}$

\subsection{Robustness of baseline results that includes real bank credit}

\subsubsection{Replace real bank credit by real total credit in the VAR specification}

\footnotetext{
${ }^{26}$ The impulse responses of the remaining structural shocks are also available upon request.
} 
Our first sensitivity test is to replace real bank credit by real total credit. Figure 4 depicts the impulse responses, while Table 4 shows the forecast error variance decomposition.

\section{INSERT FIGURE 4 HERE}

\section{INSERT TABLE 4 HERE}

The impulse responses are very similar to the baseline results, except that real GDP's response to a contractionary monetary policy shock is persistently negative. The responses of real total credit to a monetary policy shock as well as to a LTV ratio shock are also very similar to the responses of real bank credit to these two respective shocks in the baseline case. More importantly, our findings in the baseline case on the corresponding credible sets hold.

Table 4 indicates that the identified structural shocks again explain a large part (at least two-thirds) of the variations in the three variables. Although smaller compared to the baseline case, monetary policy shock still account for a large portion of the variations in the price level, and with a share of about 11 percent, its contribution to the variation in real total credit is almost as high as that of an aggregate supply shock. While the LTV ratio shock's contribution to the variation in the price level decreased slightly, its contribution to fluctuations in real GDP increased, and it also accounted for a large share of the fluctuations in real total credit.

\subsubsection{Replace real bank credit by real household credit in the VAR specification}

Our second sensitivity test is to replace real bank credit by real household credit. Figure 5 depicts the impulse responses, while Table 5 shows the forecast error variance decomposition.

\section{INSERT FIGURE 5 HERE}

\section{INSERT TABLE 5 HERE}

The impulse responses are again very similar to the baseline results, except that the policy rate's response to a contractionary monetary policy shock is persistently positive. The responses of real household credit to a monetary policy shock and to an LTV ratio shock are also very similar to the baseline case. More importantly, our findings in the baseline case on the corresponding credible sets still hold. 
The results of the variance decomposition in Table 5 indicate that the identified structural shocks again explain a large part of the variations in the three variables. Compared to the baseline case, the share of the variations in the price level accounted for by monetary policy shock is smaller. Likewise, monetary policy accounted for a smaller share of the variations in real household credit. With regard to the variations accounted for by LTV ratio shock, its contribution to the variations in the price level is very marginal, almost non-existent, whereas its contribution to the fluctuations in real GDP increased. It also accounted for a large share of the fluctuations in real household credit. Despite some differences in this part of the analysis, these disparities, however, do not substantially alter the conclusions of this study.

\subsubsection{Replace real GDP by real consumption in the VAR specification}

Our next sensitivity test is to replace GDP by real consumption. Figure 6 depicts the impulse responses and they are also very similar to the baseline results. Our findings in the baseline case on the corresponding credible sets still hold. With regard to the variance decomposition analysis, our baseline results are also reinforced. In Table 6 which shows the forecast error variance decomposition, the identified structural shocks explain a large part, this time at least three-fourths of the variations in the three variables. The monetary policy shock explains a large portion of the variations in the price level and real bank credit. While the share of the variations in the price level accounted for by LTV ratio shocks decreased, its share in the variation in real bank credit increased. LTV ratio shock also accounted for a large share in the variation of real consumption.

\section{INSERT FIGURE 6 HERE}

\section{INSERT TABLE 6 HERE}

\subsubsection{Replace real GDP by real investment in the VAR specification}

Our next sensitivity test is to replace GDP by real investment. There is practically no change in the impulse responses depicted in Figure 7 compared to the baseline results, except that the responses of the price level to a contractionary monetary shock is not anymore persistently negative as its modal model response function becomes positive after the two-year horizon. Nevertheless, our findings in the baseline case on the corresponding credible sets still hold. The results of the variance decomposition in Table 7 indicate that the identified structural shocks again explain a large part of the variations in the three variables. Compared to the baseline case, the share of the variations in the price level and real bank credit accounted for by monetary policy shock is smaller. The fluctuations in the price level and real bank credit accounted for 
by the LTV shock ratio increased, while its contribution to the variations in real investment is also large. Despite the slight differences in the variance decomposition analysis, these again do not substantially alter the conclusions of this study.

\section{INSERT FIGURE 7 HERE}

\section{INSERT TABLE 7 HERE}

\subsubsection{Replace the price level by inflation in the VAR specification}

Our next sensitivity test is to replace the price level by inflation. As depicted in Figure 8 , our baseline results on the impulse responses are again validated, except that the response of inflation to a contractionary monetary shock is not persistently negative as the response function becomes positive within one year. Our findings on the baseline credible sets are also further validated. Table 8 shows the forecast error variance decomposition. The share of the variations in inflation and real bank credit accounted for by monetary policy shock is smaller. Lastly, the fluctuations in real GDP and real bank credit accounted for by LTV shock increased. Again, these differences in the variance decomposition analysis do not have any impact on the conclusions of this study.

\section{INSERT FIGURE 8 HERE}

\section{INSERT TABLE 8 HERE}

\subsubsection{Consider an alternative identification restriction}

Recall that the baseline results impose one of the identifying sign restrictions that the central bank reacts to an adverse aggregate supply shock by increasing the interest rate (e.g., Hristov et al., (2012). However, some other VAR-based studies have left unrestricted the response of the central bank to an aggregate supply shock (for example, Eickmeier et al., 2009; Duchi and Elbourne, 2016; Bijsterbosch and Falagiarda, 2015; Finlay and Jääskelä, 2014). In this sub-section, we check the sensitivity of our baseline results by considering this alternative restriction. Figure 9 indicates that this alternative restriction does not have a material impact on the conclusions of this study. The variance decomposition analysis presented in Table 9 is almost identical to the baseline results.

INSERT FIGURE 9 HERE

INSERT TABLE 9 HERE 


\subsection{Robustness of baseline results that includes real house price}

\subsubsection{Replace real GDP by real consumption in the VAR specification}

Our first sensitivity test in this sub-section is to replace GDP by real consumption in the VAR. Figure 10 depicts the impulse responses and yet again these responses are similar to the baseline results. Our findings in the baseline case on the corresponding credible sets still hold. More importantly in this instance, the response functions of real house price are precisely enough estimated for the first three and five quarters to monetary policy and LTV ratio shocks, respectively. With regard to the variance decomposition analysis, Table 10 shows that the identified structural shocks explain a large part of the variations in the three variables. The LTV ratio shock accounted for a large portion of the variations in real consumption, while both the monetary policy and LTV shocks accounted for a large portion of the fluctuations in real house price.

\section{INSERT FIGURE 10 HERE}

\section{INSERT TABLE 10 HERE}

\subsubsection{Replace real GDP by real investment in the VAR specification}

Our second sensitivity test is to replace GDP by real investment. There is again practically no substantial difference in the impulse responses depicted in Figure 11 compared to the baseline results. Likewise, our findings in the baseline case on the corresponding credible sets are validated with the response functions of real house price precisely enough estimated for the first five quarters to monetary policy and LTV ratio shocks, respectively. The results of the variance decomposition in Table 11 indicate that the identified structural shocks yet again explain a large part of the variations in the three variables. Compared to the baseline case, while the share of the variations in the real house price is smaller, the share of the variations in the price level accounted for by monetary policy shock is larger. The bulk of the fluctuations accounted for by the LTV ratio shock remains. Despite the slight differences in the variance decomposition analysis, these again do not substantially alter the conclusions of this study.

\section{INSERT FIGURE 11 HERE}

\section{INSERT TABLE 11 HERE}

\subsubsection{Replace the price level by inflation in the VAR specification}


Our next sensitivity test is to replace the price level by inflation. As depicted in Figure 12 , our baseline results on the impulse responses are again reinforced. Our findings on the baseline credible sets are also further validated with the response functions of real house price precisely estimated for the first five and six quarters to monetary policy and LTV ratio shocks, respectively. Table 12 shows that while the share of the variations in inflation and real house price accounted for by monetary policy shock is smaller, it accounted for a large share of the variations in real GDP. Lastly, fluctuations in the price level accounted for by the LTV ratio shock decreased, whereas the variations it accounted for in real GDP and real house price increased.

\section{INSERT FIGURE 12 HERE}

\section{INSERT TABLE 12 HERE}

\subsubsection{Consider an alternative identification restriction}

In this part, we again left unrestricted the response of the central bank to an aggregate supply shock and checked the sensitivity of our baseline results. The impulse responses and the variance decomposition analysis are identical to the baseline results. ${ }^{27}$

\section{Conclusion}

The aim of this paper is to determine the real effects of a LTV ratio shock in an inflation targeting framework for the Korean economy. We then compare the effects of a LTV ratio shock to that of a monetary policy shock for this economy. Korea is used as our country study due to its consistent and homogeneous monetary policy framework. At the same time, it has pursued an active implementation of LTV limits in line with its given financial stability mandate. Using the method of structural vector autoregression, we not only identify LTV ratio and monetary policy shocks, but also additionally account for aggregate demand and aggregate demand shocks. We identify these shocks using the modern technique of sign restrictions, and employ the recent innovation introduced by Inoue and Kilian (2013) to identify the structural shocks and conduct structural inference. One of our baseline findings indicates that both shocks in monetary policy and LTV ratio have effects on real output, which were validated by several robustness tests. We also find, in one of our robustness tests, that both shocks have effects on real consumption and real investment. While by construction we avoid the price puzzle of monetary policy, our baseline results indicate that LTV ratio shocks have negligible effects on the price level. This finding is mainly supported by a battery

\footnotetext{
${ }^{27}$ These results are available upon request.
} 
of robustness tests. We also obtained evidence that both monetary policy and LTV ratio shocks have effects on real bank credit, which were found to be robust to alternative measures of credit such as real total credit and real household credit. Finally, both shocks also have non-negligible effects on real house prices, evidence that was also confirmed by our extensive robustness tests.

From a practical standpoint, our findings indicate that LTV limits have important macroeconomic consequences. For instance, for the period covered by this study, LTV limits achieved their financial stability objectives in Korea in terms of limiting credit and house price appreciation under an inflation targeting regime. Furthermore, they attained these objectives without posing any threat to its price stability objective. 


\section{References}

Alam Z, Alter A, Eiseman J, Gelos G, Kang H, Narita M, Nier E, Wang N (2019) Digging Deeper-Evidence on the effects of macroprudential policies from a new database. IMF Working Paper Series, International Monetary Fund.

Alpanda S, Zubairy S (2017) Addressing Household Indebtedness: Monetary, Fiscal or Macroprudential Policy? European Economic Review 92:47-73.

Ardakani O, Kishor K, Song S (2018) Re-evaluating the effectiveness of inflation targeting. J Econ Dyn Control 90:76-97.

Baumeister C, Peersman G (2013) The role of time-varying price elasticities in accounting for volatility changes in the crude oil market. J Appl Econom 28(7):1087-1109.

Bijsterbosch M, Falagiarda M (2015) The macroeconomic impact of financial fragmentation in the euro area: Which role for credit supply? J Int Money Financ 54:93-115.

Blanchard O, Watson M (1986) Are all business cycles alike? In: Gordon, R. (Ed.), The American Business Cycle, University of Chicago Press, Chicago, pp. 123160.

Caldara D, Kamps C (2017) The analytics of SVARs: A unified framework to measure multipliers. Rev Econ Stud 84(3):1015-1040.

Canova F, Pappa E (2007) Price dispersions in monetary unions: The role of fiscal shocks. Econ J 117:713-737.

Canova F, De Nicolo G (2003) On the sources of business cycles in the G-7. J Int Econ 59(1):77-100.

Canova F, De Nicolo G (2002) Monetary disturbances matter for business fluctuations in the G-7. J Monet Econ 49:1131-1159.

Carreras O, Davis P, Piggott R (2018) Assessing macroprudential tools in OECD countries within a cointegration framework. J Financ Stab 37:112-130.

Cerutti E, Claessens S, Laeven L (2017) The use and effectiveness of macroprudential policies: New evidence. J Financ Stab 28:203-224.

Christiano LJ, Eichenbaum M, Evans C (1999) Monetary policy shocks: What have we learned and to what end? In: Woodford M, Taylor J (eds) Handbook of Macroeconomics, vol 1. Elsevier Science, New York, pp. 65-148.

Dedola N, Neri S (2007) What does a technology shock do? A VAR analysis with model-based sign restrictions. J Monet Econ 54:512-549. 
Del Negro M, Otrok C (2007) '99 Luftballons: Monetary policy and the house price boom across US states. J Monet Econ 54(7):1962-1985.

Duchi F, Elbourne A (2016) Credit supply shock. J Macroecon 50:51-71.

Eickmeier S, Hofmann B, Worms A (2009) Macroeconomic fluctuations and bank lending: Evidence for Germany and the Euro Area. Ger Econ Rev 10(2):193-223.

Faust J (1998) The robustness of identified VAR conclusions about money. CarnegieRochester conference series on public policy, vol 49, pp. 207-244.

Fendoglu S (2017) Credit cycles and capital flows: Effectiveness of the macroprudential policy framework in emerging market economies. J Bank Finan 79:110-128.

Financial Stability Board (2017) Peer Review of Korea.

Finlay R, Jääskelä, J (2014) Credit supply shocks and the global financial crisis in three small open economies. J Macroecon 40:270-276.

Fouejieu A (2017) Inflation targeting and financial stability in emerging markets. Econ Model 60:51-70.

Fry R, Pagan A (2011) Sign restrictions in structural vector autoregressions: a critical review. J Econ Lit 49(4): 938-960.

Galati G, Moessner R (2018) What do we know about the effects of macroprudential policy? Economica 85(340):735-770.

Glocker C, Towbin P (2015) Reserve requirements as a macroprudential instrument-empirical evidence from Brazil. J Macroecon 44:158:176.

Goodhart C, Hofmann B (2008) House prices, money, credit, and the macroeconomy. Oxf Rev Econ Policy 24(1):180-205.

Greenwood-Nimmo M, Tarassow A (2016) Monetary policy shocks, macroprudential shocks and financial stability. Econ Model 56:11-24.

Hristov N, Hülsewig O, Wollmershäuser T (2012) Loan supply shocks during the financial crisis: Evidence for the Euro Area. J Int Money Financ 31:569-592.

Igan D, Kang H (2011) Do loan-to-value and debt -to-income limits work? Evidence from Korea. IMF Working Paper Series, International Monetary Fund. 
Inoue A, Kilian L (2013) Inference on impulse response functions in structural VAR models. J Econom 177:1-13.

in't Veld J, Kollmann R, Pataracchia B, Ratto M, Roeger W (2014) International capital flows and the boom-bust cycle in Spain. J Int Money Financ 48:314-335.

IMF-FSB-BIS (2016) Elements of effective macroprudential policies: Lessons from international experience. Mimeo.

International Monetary Fund (2013) The interaction of monetary and macroprudential policies. International Monetary Fund.

Jarociński M, Smets FR (2008) House prices and the stance of monetary policy. Federal Reserve Bank of St. Louis Review 90(4):339-365.

Jeanneau S (2014) Financial stability objectives and arrangements - what's new? BIS Papers No 76. Bank for International Settlements.

Jung H, Lee J (2017) The effects of macroprudential policies on house prices: evidence from an event study using Korea real transaction data. J Financ Stab 31:167-185.

Jung Y, Kim S, Yang DY (2017) Optimal macroprudential policies and house prices in Korea. Emerg Mark Financ Trade 53:2419-2439.

Kilian L, Lütkepohl H (2017) Structural vector autoregressive analysis. Cambridge University Press.

Kilian L, Murphy D (2014) The role of inventories and speculative trading in the global market for crude oil. J Appl Econom 29:454-478.

Kilian L, Murphy D (2012) Why agnostic sign restrictions are not enough: Understanding the dynamics of oil market VAR models. J Eur Econ Assoc 10:1166-1188.

Kim S, Mehrotra A (2018) Effects of monetary and macroprudential policies-evidence from four inflation targeting economies. J Money Credit Bank 50(5):967-992.

Kim, C (2014) Korea's experiences with macroprudential policy. In: Akerlof G, Blanchard O, Romer D, Stiglitz J (eds) What have we learned? Macroeconomic policy after the crisis, IMF and MIT, Cambridge, pp. 99-126.

Lee, JK (2013) The operation of macro prudential policy measures: The case of Korea in the 2000s. In: Canuto O, Ghosh S (eds) Dealing with the Challenges of Macro Financial Linkages in Emerging Markets, World Bank, Washington DC, pp. 227-279. 
Lippi F, Nobili A (2012) Oil and the macroeconomy: A quantitative structural analysis. J Eur Econ Assoc 10:1059-1083.

Mishkin F (2012) Central banking after the crisis. mimeo.

Morgan P, Regis P, Salike N (2019) LTV policy as a macro-prudential tool: the case of residential mortgage loans. J Financ Intermed 37:89-103.

Mountford A, Uhlig H (2009) What are the effects of fiscal policy shocks? J Appl Econom 24:960-992.

Pappa E (2009) The effects of fiscal shocks on employment and real wages. Int Econ Rev 50:217-244.

Peersman G, Straub R (2009) Technology shocks and robust sign restrictions in a euro area SVAR. Int Econ Rev 50:727-750.

Peersman G (2005) What caused the early millennium slowdown? Evidence based on vector autoregressions. J Appl Econom 20:185-207.

Richter B, Schularick M, Shim I (2019) The costs of macroprudential policy. J Int Econ 118:263-282.

Sá F, Towbin P, Wieladek T (2014) Low interest rates and housing booms: capital inflows, monetary policy and the effects of financial innovation. J Eur Econ Assoc 12(2):522-546.

Shim I, Bogdanova B, Shek J, Subelyte A (2013) A database for policy actions on housing markets. BIS Quarterly Review, Bank for International Settlements.

Sims CA, Zha T (1999) Error bands for impulse responses. Econom 67:1113-1155.

Sims CA (1998) Comment on Glenn Rudebusch's Do measures of monetary policy in a VAR make sense? Int Econ Rev 39(4): 933-941.

Sims CA (1992) Interpreting the macroeconomic time series facts: The effects of monetary policy. Eur Econ Rev 36(5):975-1000.

Sims CA (1980) Macroeconomics and reality. Econometrica 48:1-48.

Tillmann P (2015) Estimating the effects of macroprudential policy shocks: A Qual VAR approach. Econ Lett 135:1-4. 
Uhlig H (2005) What are the effects of monetary policy on output? Results from an agnostic identification. J Monet Econ 52:381-419.

Ume E (2018) The impact of monetary policy on housing market activity: An assessment using sign restrictions. Econ Model 68:23-31.

Zha T (1997) Identifying monetary policy: A primer. Federal Reserve Bank of Atlanta Economic Review, vol. 82 (2), pp. 26-43. 
Figure 1

Tightening and loosening episodes of average LTV Limits in Korea

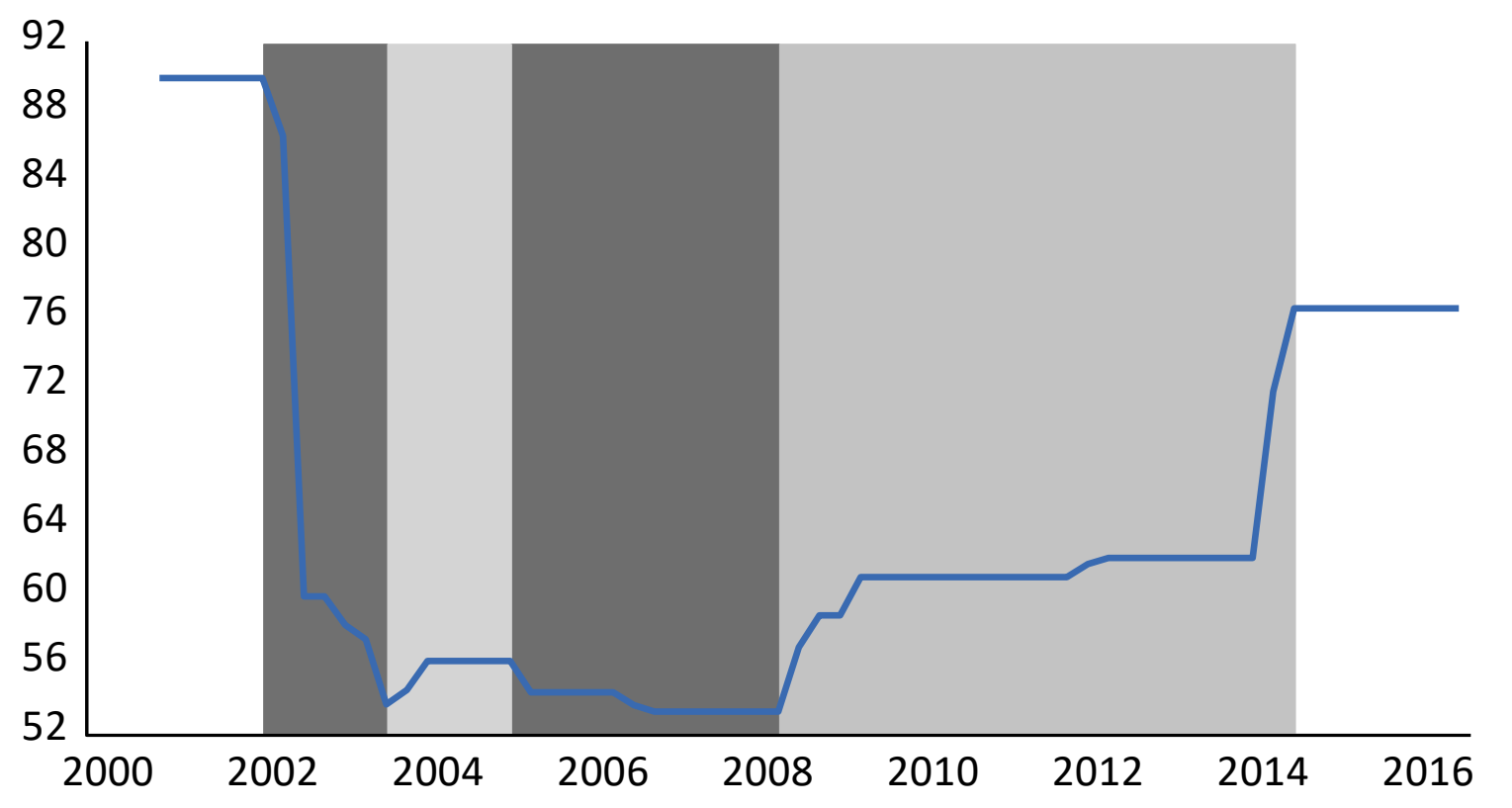

Notes: $\quad$ Dark-coloured shaded area - Tightening episodes $\quad$ Light-coloured shaded area - Loosening episodes

Refer to main text for discussion of each episodes.

Source: Raw data obtained from Alam et al., (2019). 


\section{Figure 2}

Impulse responses to a monetary policy shock and a shock on Loan-to-Value (LTV) limit in the baseline specification that includes real bank credit
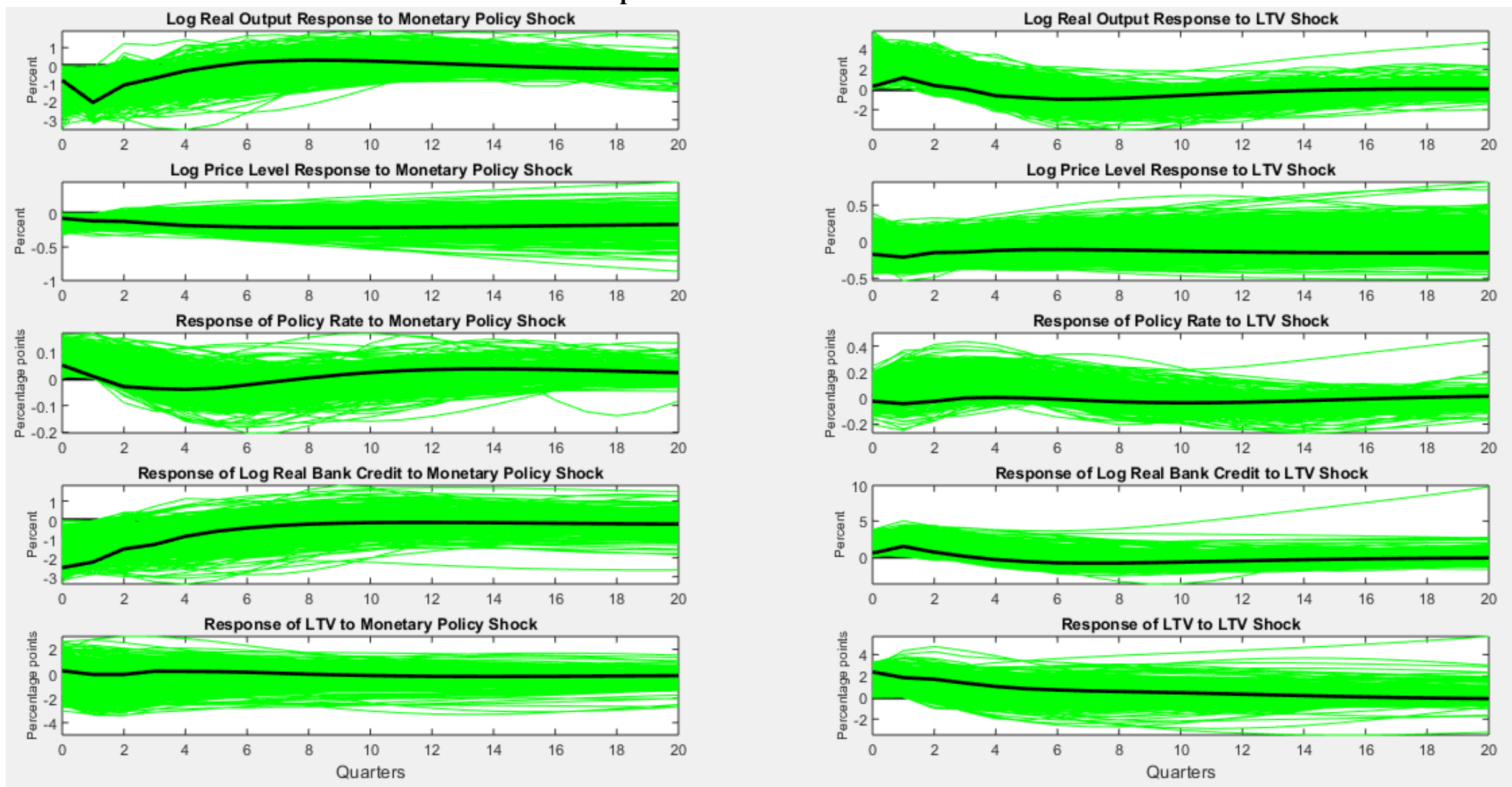

Note: The line depicts the response at each horizon in the modal model, while the shaded area represents the $68 \%$ joint regions of high posterior density. 


\section{Figure 3}

Impulse responses to a monetary policy shock and a shock on Loan-to-Value (LTV) limit in the baseline specification that includes real house price
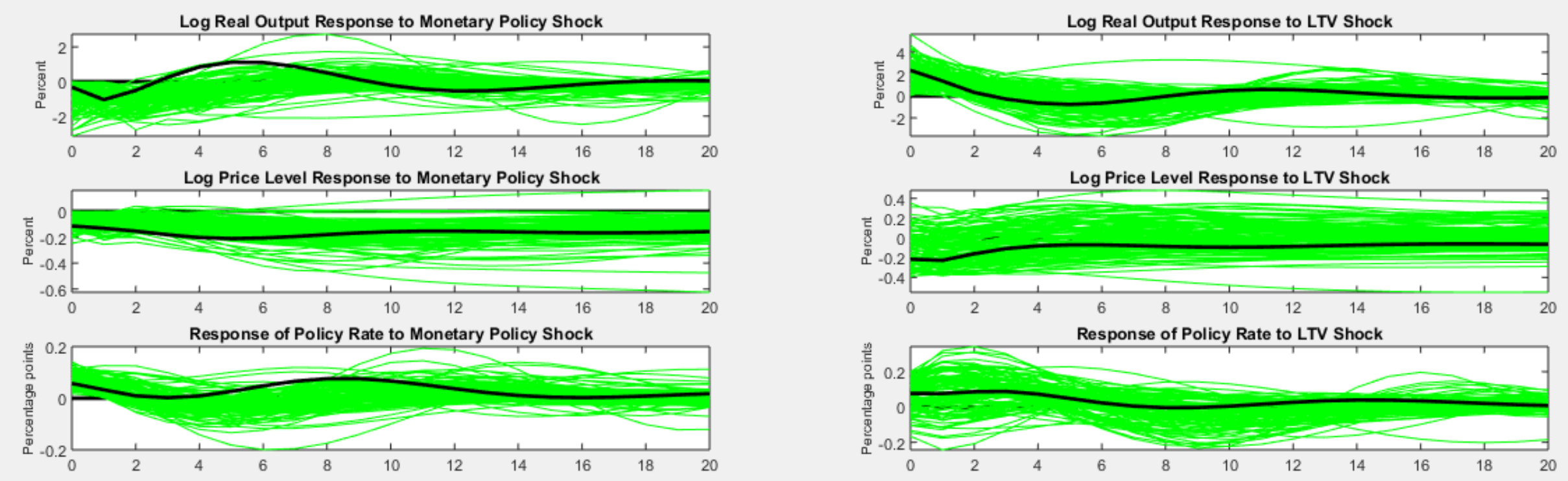

Response of Log Real House Price to Monetary Policy Shock

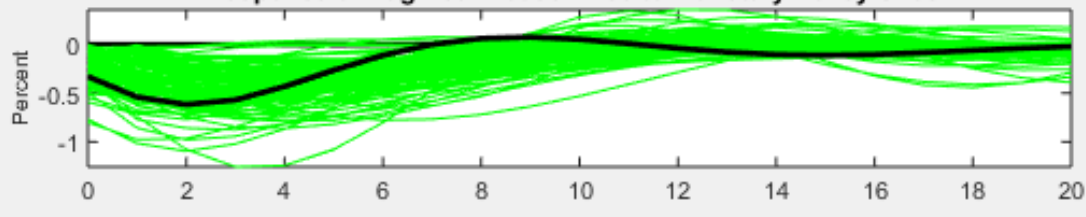

Response of Log Real House Price to LTV Shock
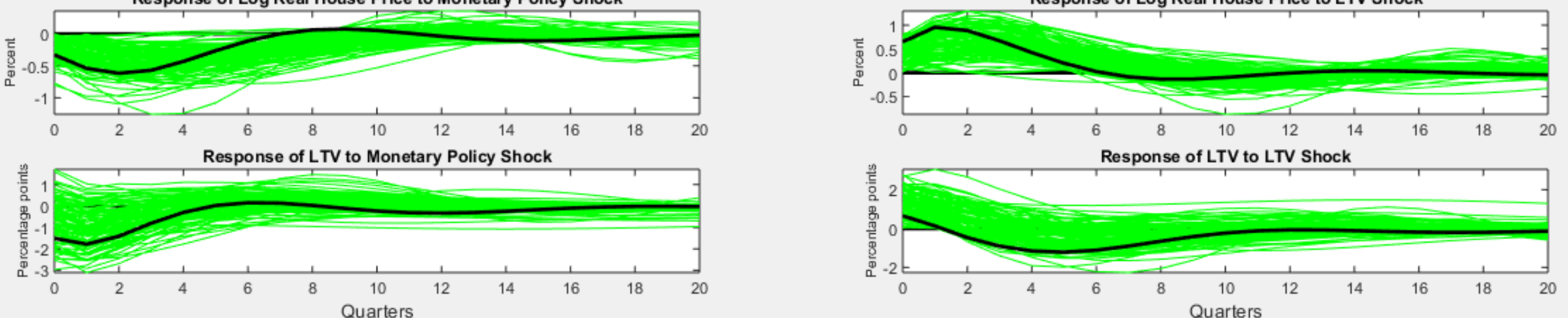

Note: The line depicts the response at each horizon in the modal model, while the shaded area represents the $68 \%$ joint regions of high posterior density. 


\section{Figure 4}

Impulse responses to a monetary policy shock and a shock on Loan-to-Value (LTV) limit:

Robustness test with real total credit as measure of credit
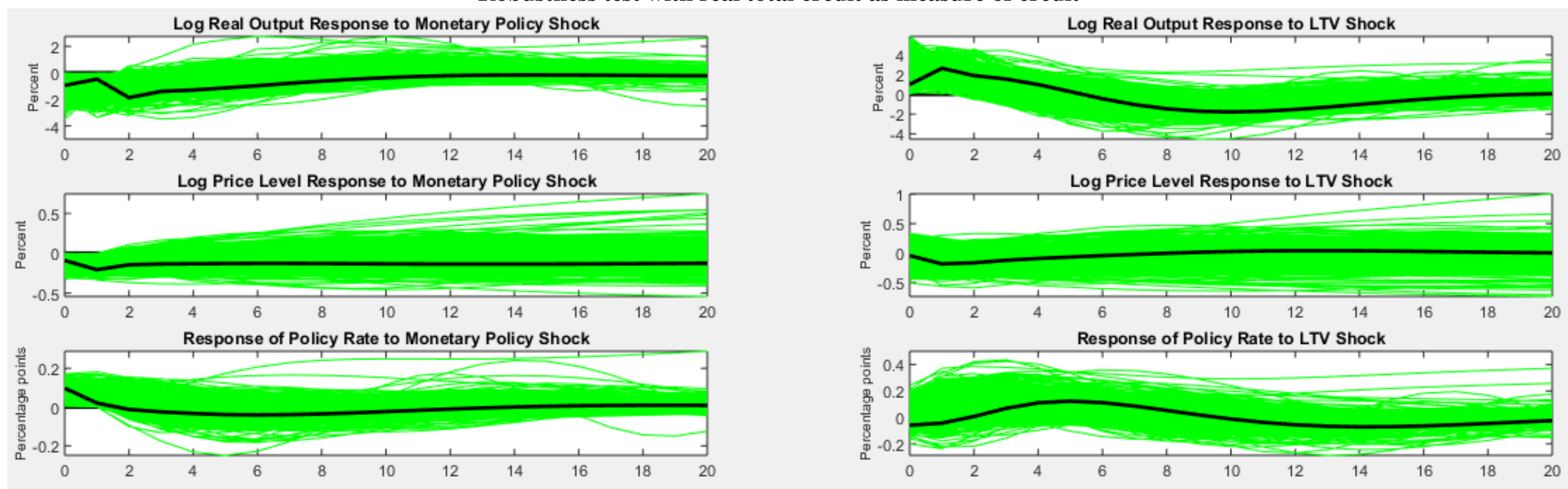

Response of Log Real Total Credit to Monetary Policy Shock

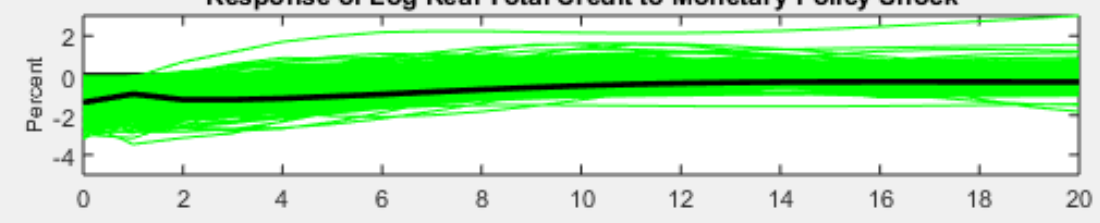

Response of Log Real Total Credit to LTV Shock
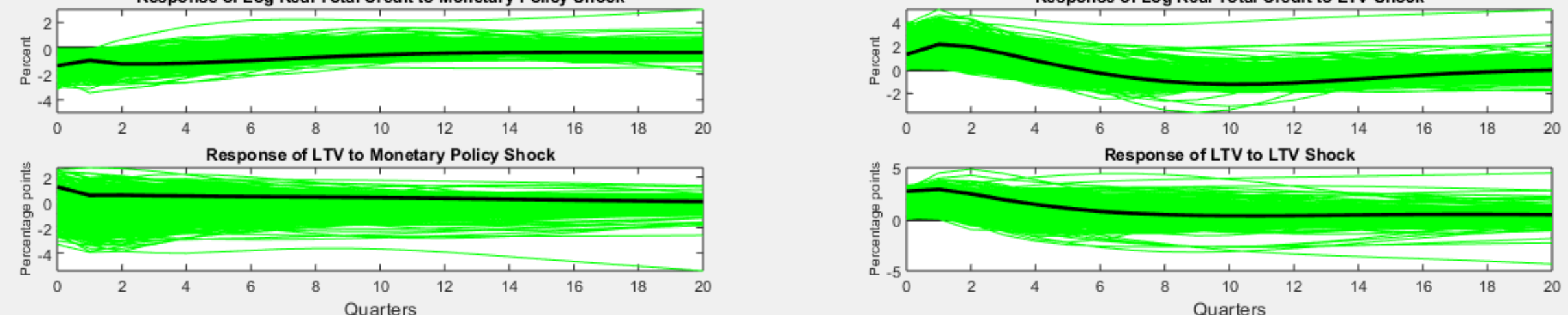

Note: The line depicts the response at each horizon in the modal model, while the shaded area represents the $68 \%$ joint regions of high posterior density. 


\section{Figure 5}

Impulse responses to a monetary policy shock and a shock on Loan-to-Value (LTV) limit:

Robustness test with real household credit as measure of credit
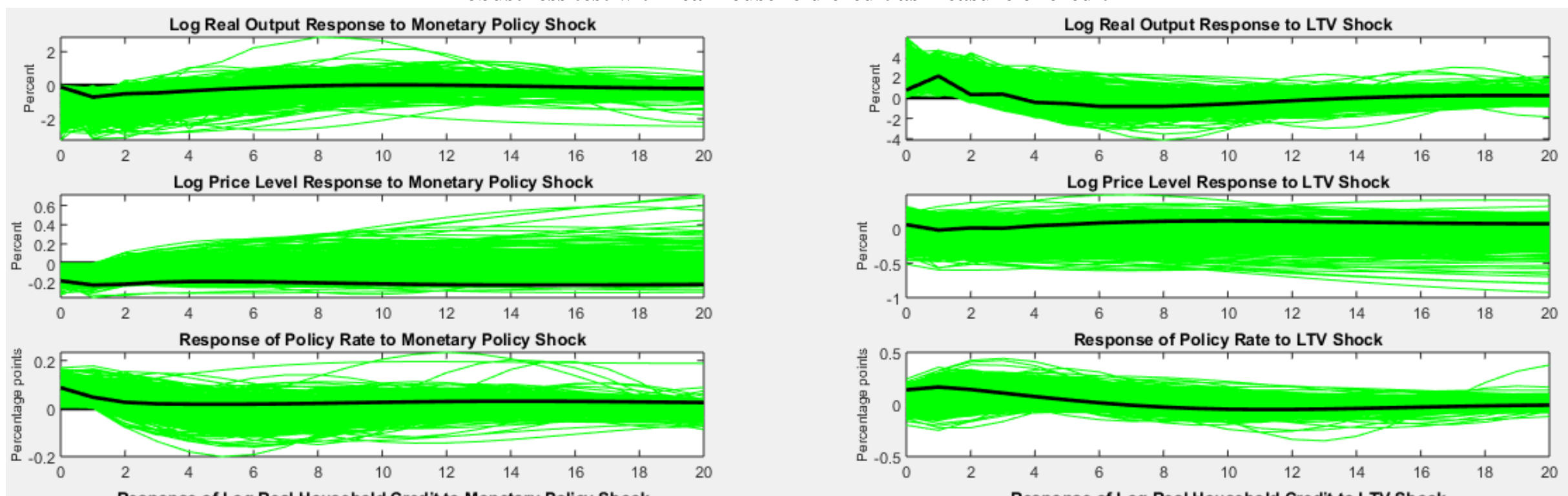

Response of Log Real Household Credit to Monetary Policy Shock

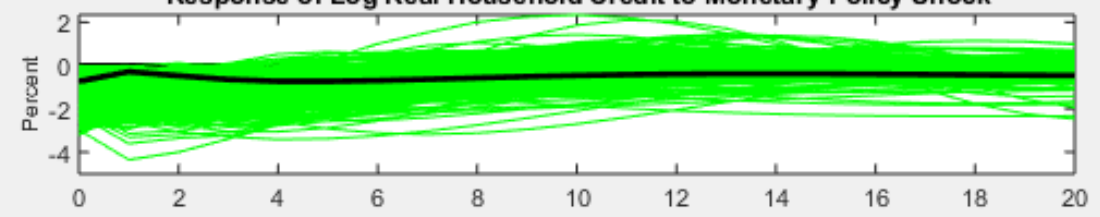

Response of LTV to Monetary Policy Shock
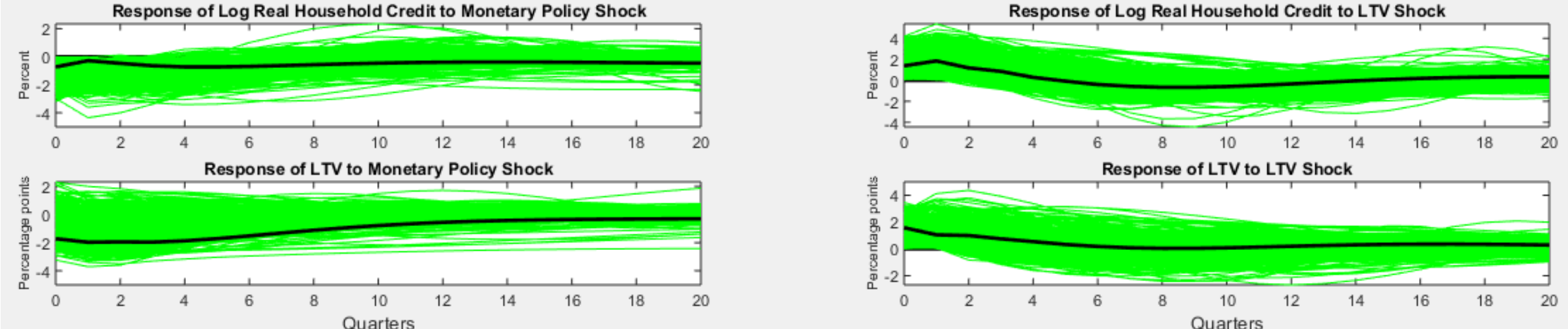

Note: The line depicts the response at each horizon in the modal model, while the shaded area represents the $68 \%$ joint regions of high posterior density. 


\section{Figure 6}

Impulse responses to a monetary policy shock and a shock on Loan-to-Value (LTV) limit:

Robustness test includes real consumption and real bank credit


Note: The line depicts the response at each horizon in the modal model, while the shaded area represents the $68 \%$ joint regions of high posterior density. 


\section{Figure 7}

Impulse responses to a monetary policy shock and a shock on Loan-to-Value (LTV) limit:

Robustness test includes real investment and real bank credit

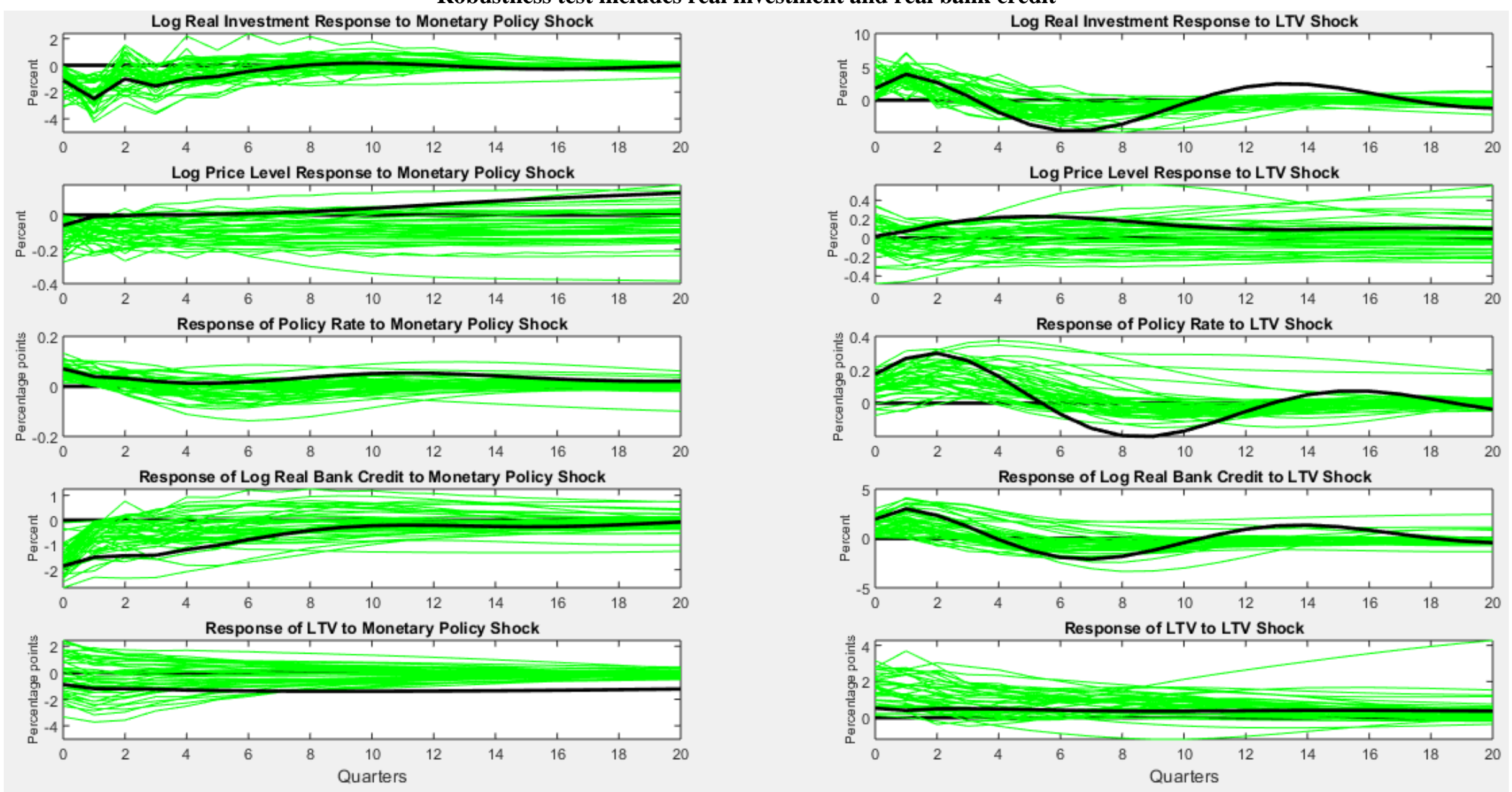

Note: The line depicts the response at each horizon in the modal model, while the shaded area represents the $68 \%$ joint regions of high posterior density. 


\section{Figure 8}

Impulse responses to a monetary policy shock and a shock on Loan-to-Value (LTV) limit:

Robustness test includes real bank credit and inflation
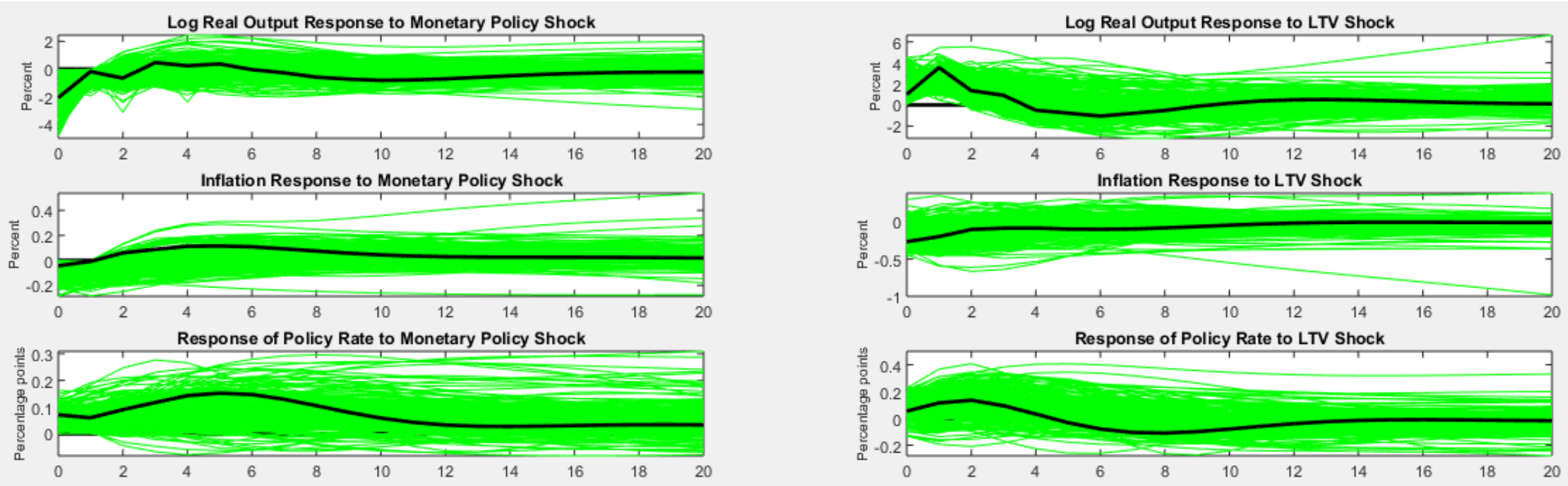

Response of Log Real Bank Credit to Monetary Policy Shock

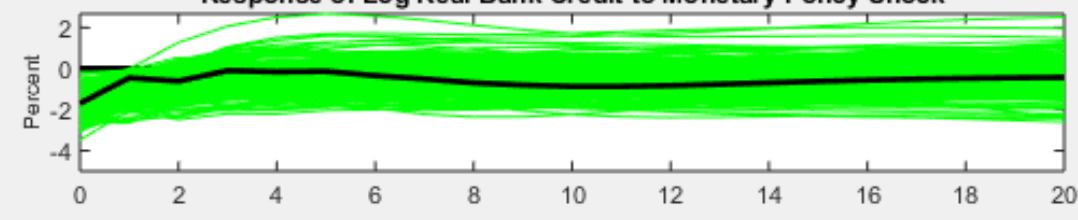

Response of LTV to Monetary Policy Shock
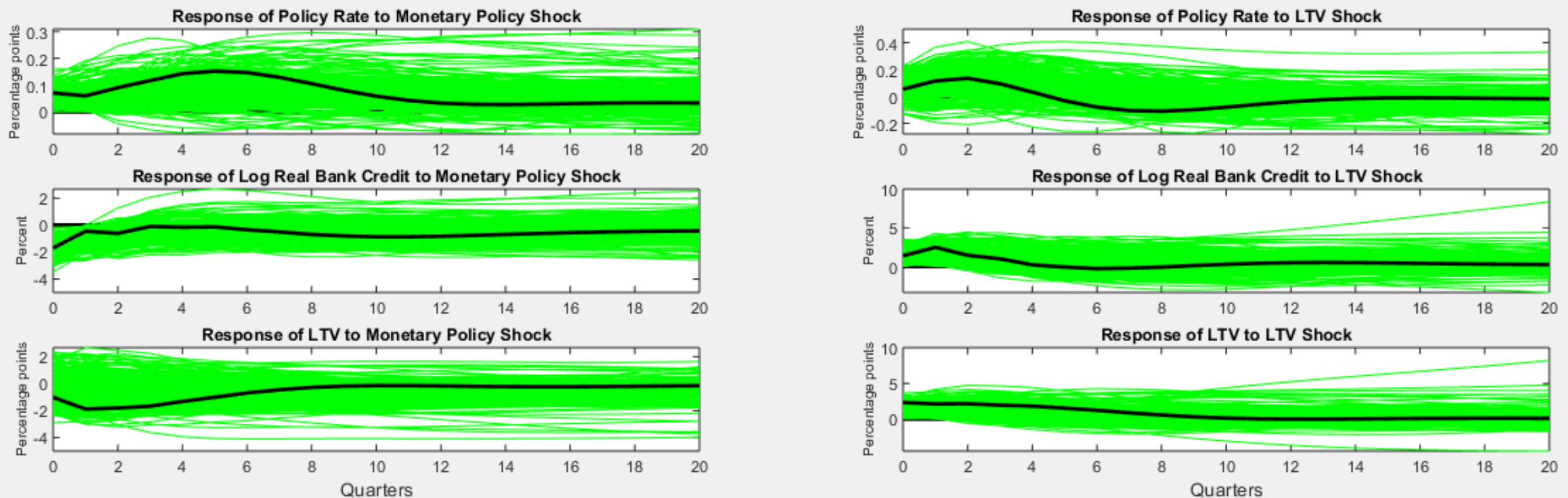

Note: The line depicts the response at each horizon in the modal model, while the shaded area represents the $68 \%$ joint regions of high posterior density. 


\section{Figure 9}

Impulse responses to a monetary policy shock and a shock on Loan-to-Value (LTV) limit:

Robustness test alternative identification restriction and includes real bank credit

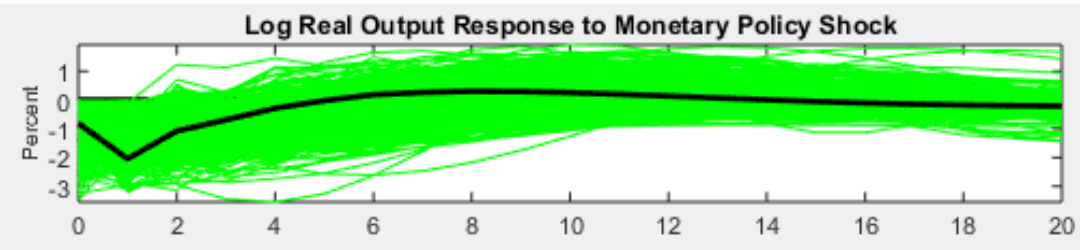

Log Price Level Response to Monetary Policy Shock

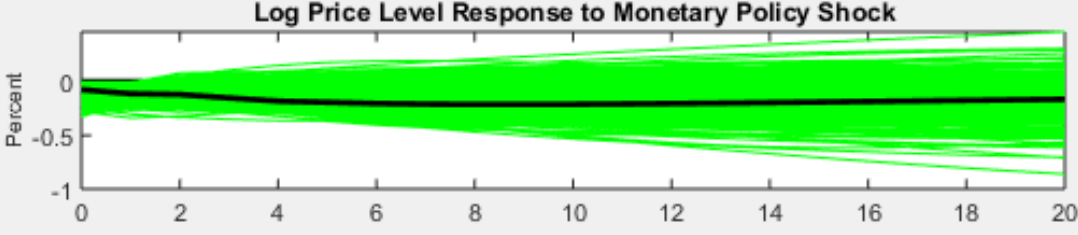

Response of Policy Rate to Monetary Policy Shock

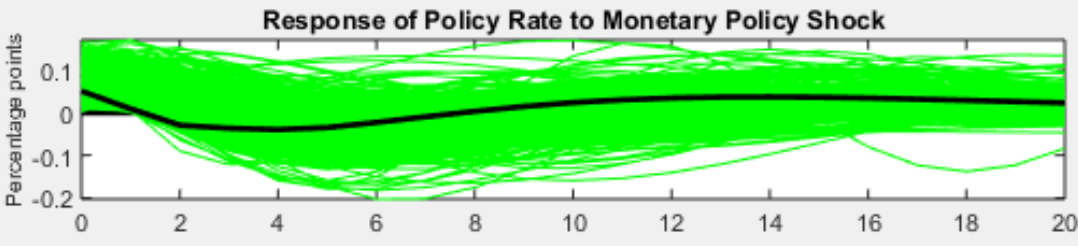

Response of Log Real Bank Credit to Monetary Policy Shock

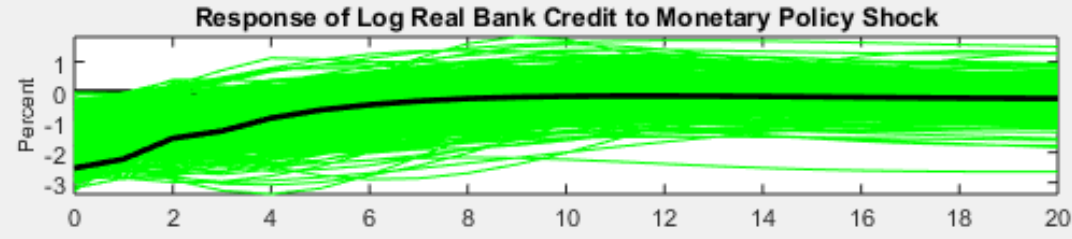

Response of LTV to Monetary Policy Shock
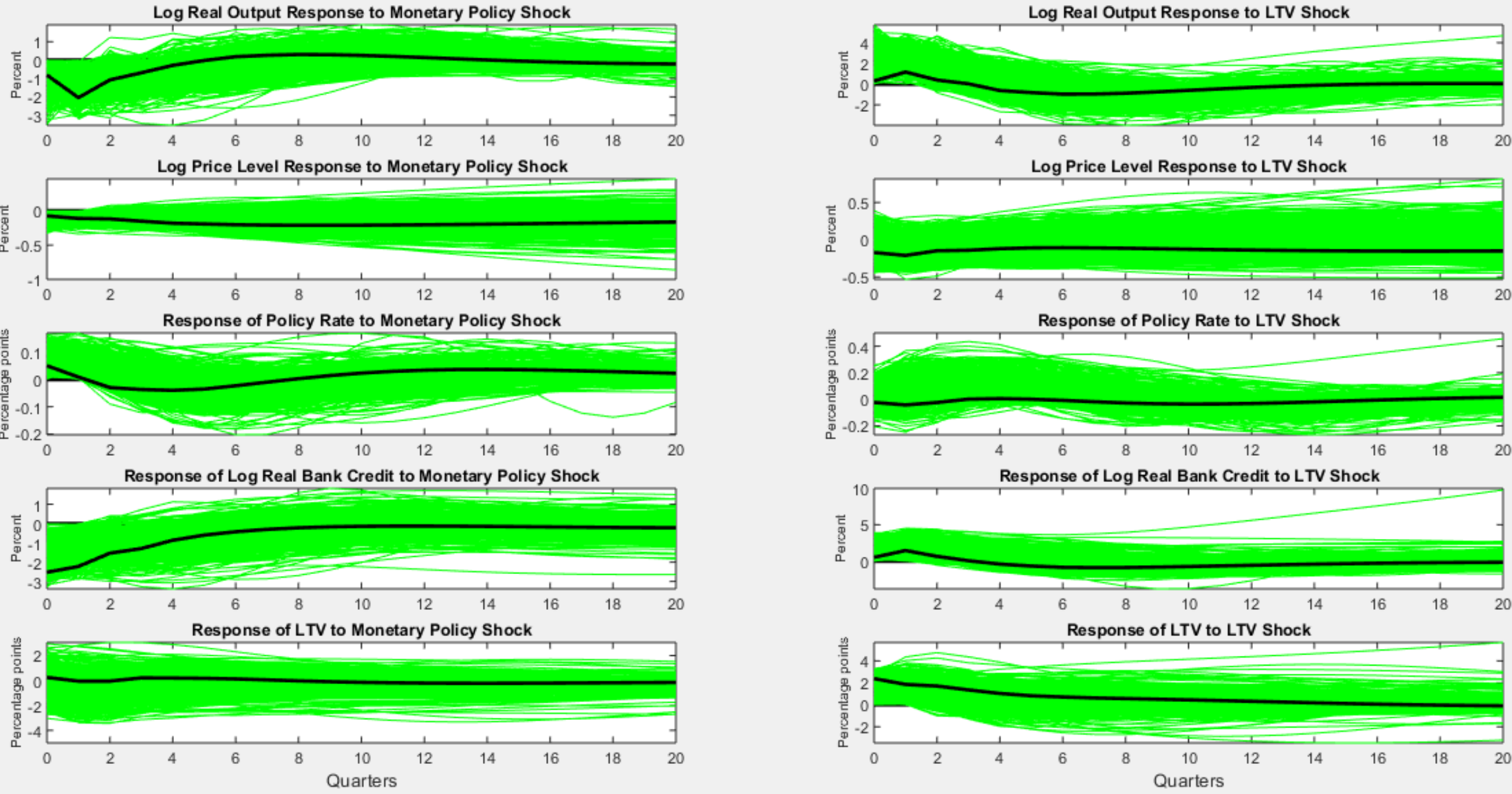

Log Price Level Response to LTV Shock
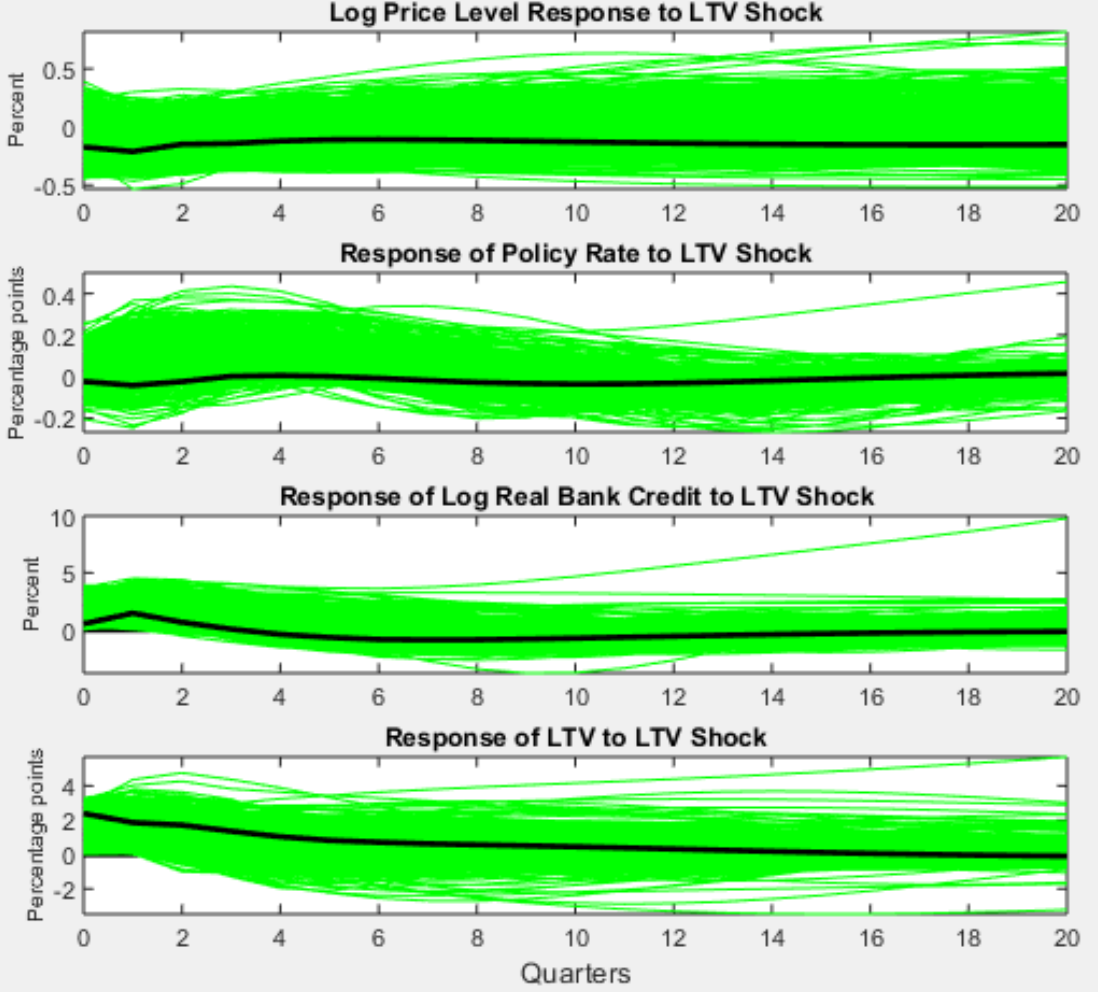

Note: The line depicts the response at each horizon in the modal model, while the shaded area represents the $68 \%$ joint regions of high posterior density. 


\section{Figure 10}

Impulse responses to a monetary policy shock and a shock on Loan-to-Value (LTV) limit:

Robustness test includes real consumption and real house price
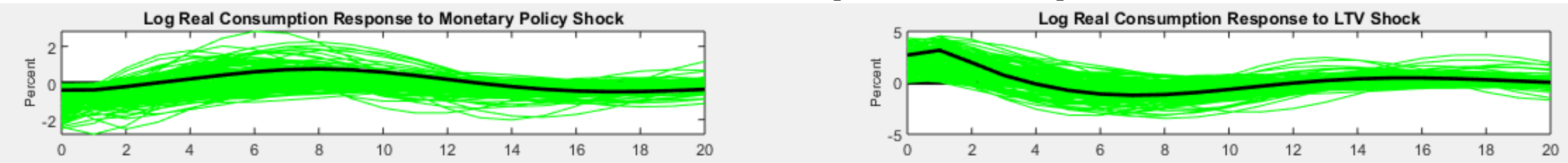

Log Price Level Response to Monetary Policy Shock
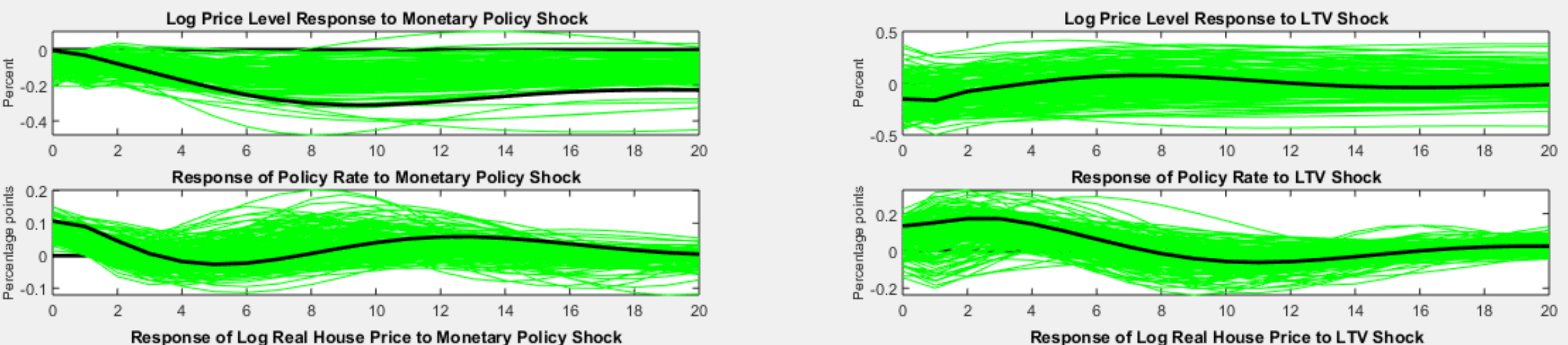

Response of Log Real House Price to Monetary Policy Shock

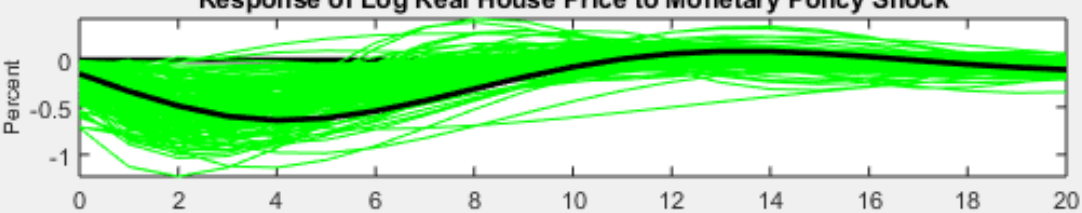

Response of LTV to Monetary Policy Shock
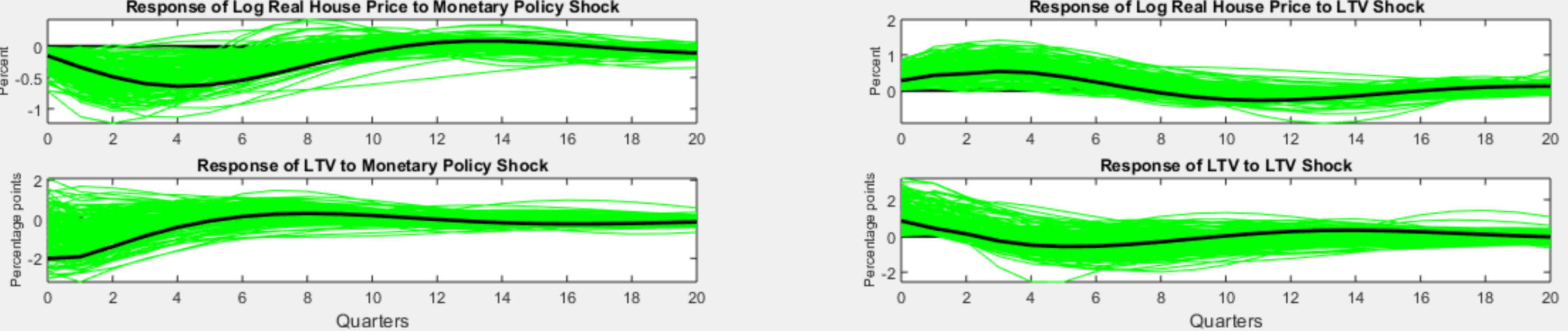

Note: The line depicts the response at each horizon in the modal model, while the shaded area represents the $68 \%$ joint regions of high posterior density. 


\section{Figure 11}

Impulse responses to a monetary policy shock and a shock on Loan-to-Value (LTV) limit:

Robustness test includes real investment and real house price

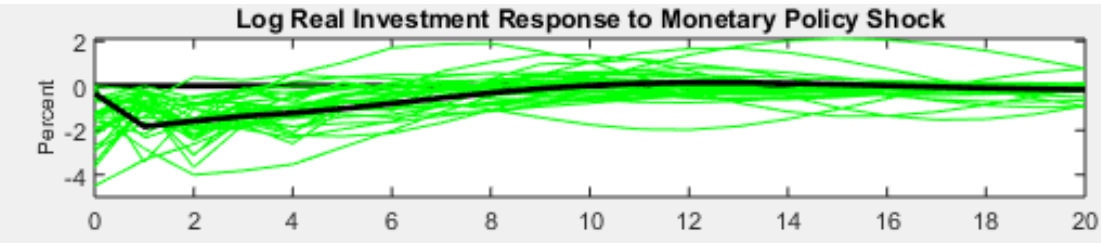

Log Price Level Response to Monetary Policy Shock

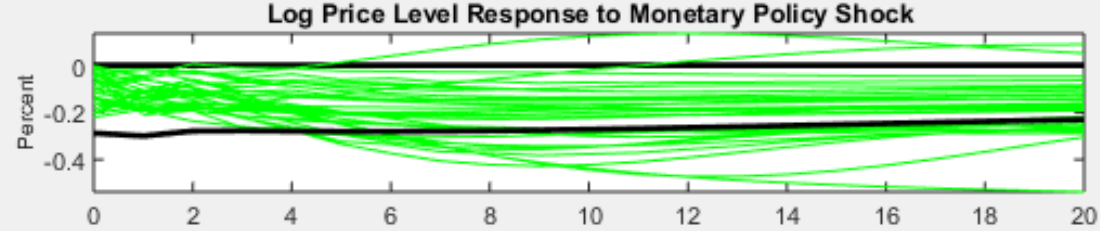

Response of Policy Rate to Monetary Policy Shock
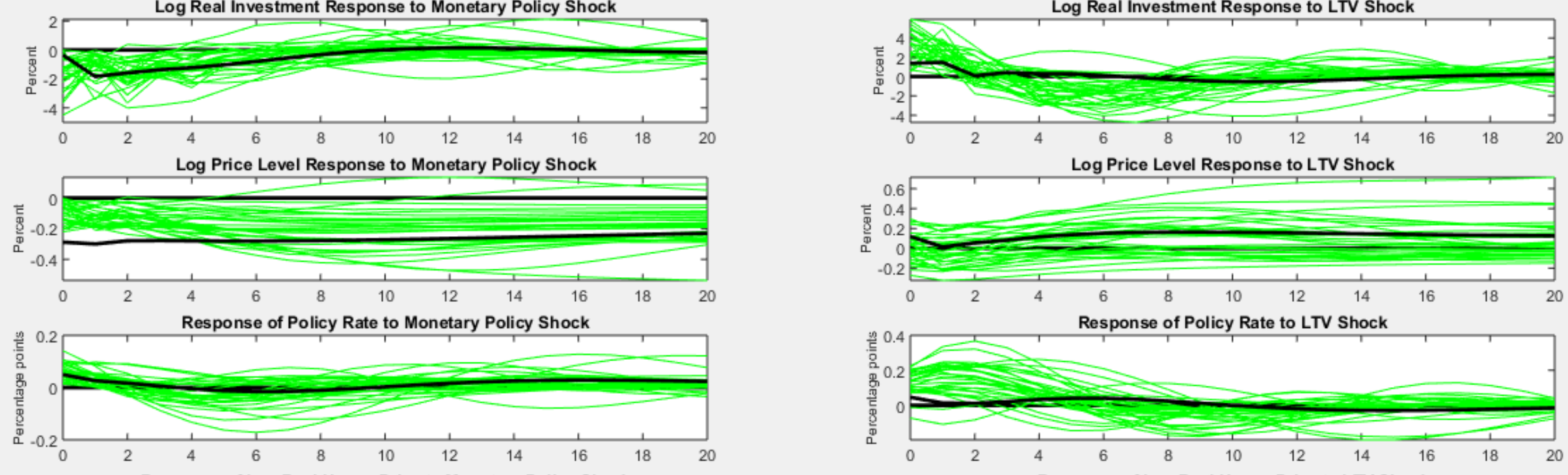

Log Price Level Response to LTV Shock

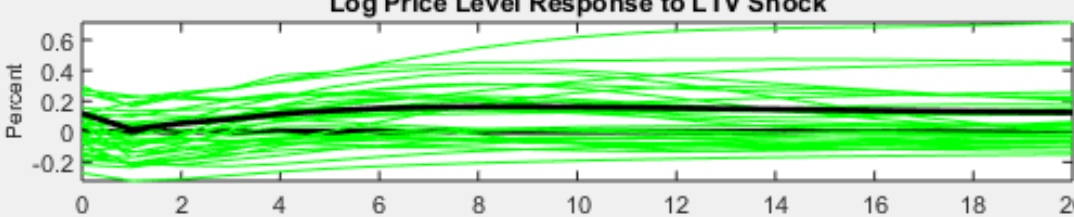

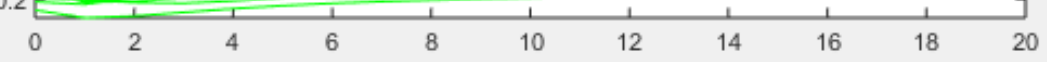

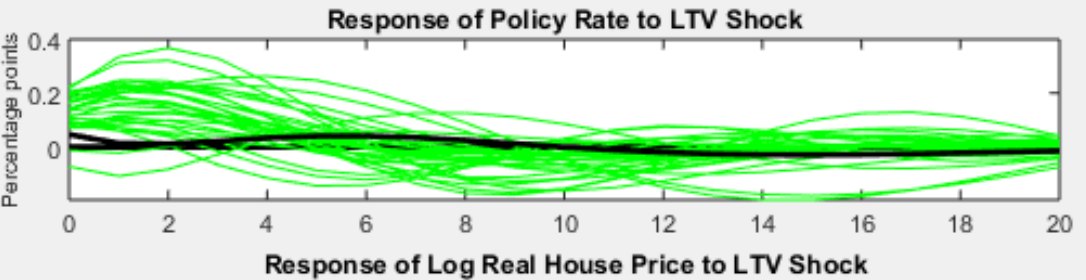

Response of Log Real House Price to Monetary Policy Shock
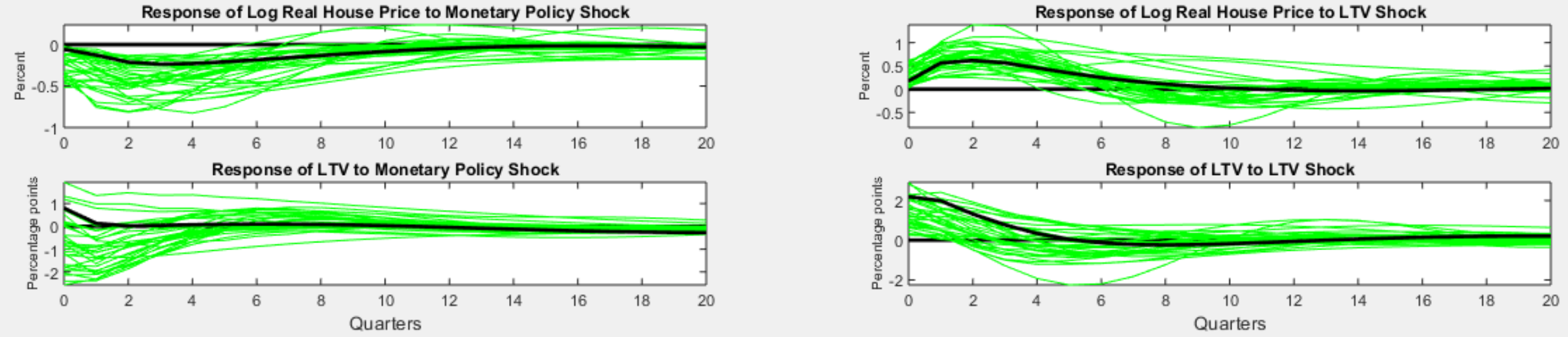

Note: The line depicts the response at each horizon in the modal model, while the shaded area represents the $68 \%$ joint regions of high posterior density. 
Figure 12

Impulse responses to a monetary policy shock and a shock on Loan-to-Value (LTV) limit:

Robustness test includes real house price and inflation
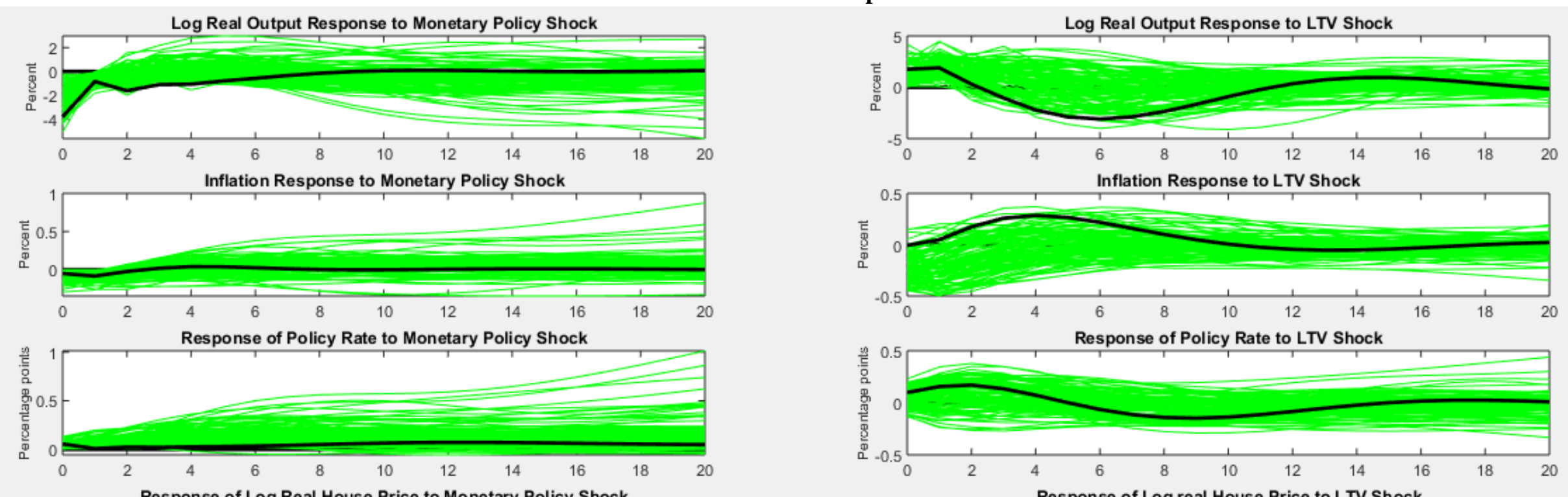

Response of Log Real House Price to Monetary Policy Shock
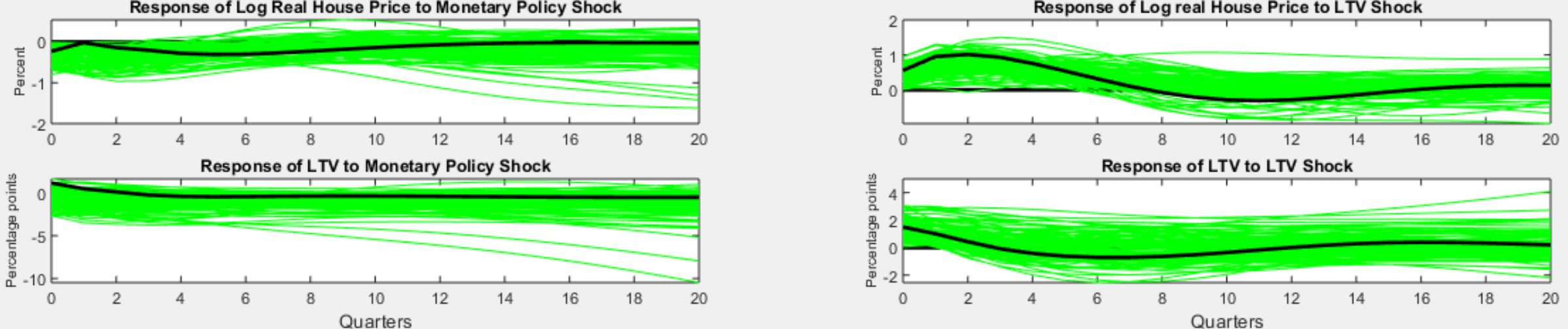

Note: The line depicts the response at each horizon in the modal model, while the shaded area represents the $68 \%$ joint regions of high posterior density. 
Table 1.A

Sign restrictions

\begin{tabular}{cccccc}
\hline \multirow{2}{*}{ Shocks/Variables } & $(1)$ & $(2)$ & $(3)$ & $(4)$ & $(5)$ \\
& & & & & \\
& rgdp & price & polrate & rbcredit & ltv \\
\hline AD shock & + & + & + & $\times$ & $\times$ \\
AS shock & - & + & + & $\times$ & $\times$ \\
MP shock & - & - & + & - & $\times$ \\
LTV shock & + & $\times$ & $\times$ & + & + \\
\hline
\end{tabular}

Table 1.B

Sign restrictions

\begin{tabular}{cccccc}
\hline & $(1)$ & $(2)$ & $(3)$ & $(4)$ & $(5)$ \\
Shocks/Variables & & & & & \\
& rgdp & price & polrate & rhsprice & ltv \\
\hline AD shock & + & + & + & $\times$ & $\times$ \\
AS shock & - & + & + & $\times$ & $\times$ \\
MP shock & - & - & + & - & $\times$ \\
LTV shock & + & $\times$ & $\times$ & + & + \\
\hline
\end{tabular}

Note: For the definition of the shocks/variables refer to the main text. 
Table 2

Forecast error variance decomposition in the baseline specification that includes real bank credit (in per cent)

\begin{tabular}{|c|c|c|c|c|c|c|}
\hline & Year & $\begin{array}{l}\text { Loan-to-value } \\
\text { limit shock }\end{array}$ & $\begin{array}{c}\text { Monetary } \\
\text { policy shock }\end{array}$ & $\begin{array}{c}\text { Aggregate } \\
\text { demand shock }\end{array}$ & $\begin{array}{c}\text { Aggregate } \\
\text { Supply shock }\end{array}$ & $\begin{array}{c}\text { Sum of } \\
\text { all shocks }\end{array}$ \\
\hline \multirow[t]{5}{*}{ Real GDP (in log) } & $1^{\mathrm{st}}$ & 5 & 11 & 35 & 37 & 88 \\
\hline & $2^{\text {nd }}$ & 5 & 10 & 38 & 33 & 86 \\
\hline & $3^{\text {rd }}$ & 8 & 9 & 39 & 31 & 87 \\
\hline & $4^{\text {th }}$ & 9 & 9 & 38 & 32 & 88 \\
\hline & $5^{\text {th }}$ & 8 & 9 & 38 & 31 & 86 \\
\hline \multirow[t]{5}{*}{ Price level (in log) } & $1^{\text {st }}$ & 23 & 11 & 13 & 19 & 66 \\
\hline & $2^{\text {nd }}$ & 16 & 26 & 14 & 22 & 78 \\
\hline & $3^{\text {rd }}$ & 11 & 37 & 13 & 22 & 83 \\
\hline & $4^{\text {th }}$ & 9 & 43 & 12 & 22 & 86 \\
\hline & $5^{\text {th }}$ & 8 & 48 & 12 & 22 & 90 \\
\hline \multirow[t]{5}{*}{ Real bank credit (in log) } & $1^{\text {st }}$ & 9 & 47 & 33 & 4 & 93 \\
\hline & $2^{\text {nd }}$ & 8 & 48 & 28 & 3 & 87 \\
\hline & $3^{\text {rd }}$ & 8 & 46 & 28 & 5 & 87 \\
\hline & $4^{\text {th }}$ & 8 & 45 & 27 & 7 & 87 \\
\hline & $5^{\text {th }}$ & 8 & 45 & 26 & 7 & 86 \\
\hline
\end{tabular}


Table 3

Forecast error variance decomposition in the baseline specification that includes real house price (in per cent)

\begin{tabular}{|c|c|c|c|c|c|c|}
\hline & Year & $\begin{array}{l}\text { Loan-to-value } \\
\text { limit shock }\end{array}$ & $\begin{array}{c}\text { Monetary } \\
\text { policy shock }\end{array}$ & $\begin{array}{c}\text { Aggregate } \\
\text { demand shock }\end{array}$ & $\begin{array}{c}\text { Aggregate } \\
\text { Supply shock }\end{array}$ & $\begin{array}{c}\text { Sum of } \\
\text { all shocks }\end{array}$ \\
\hline \multirow[t]{5}{*}{ Real GDP (in log) } & $1^{\text {st }}$ & 14 & 3 & 26 & 53 & 96 \\
\hline & $2^{\text {nd }}$ & 12 & 3 & 28 & 50 & 93 \\
\hline & $3^{\text {rd }}$ & 12 & 3 & 30 & 48 & 93 \\
\hline & $4^{\text {th }}$ & 12 & 4 & 29 & 49 & 94 \\
\hline & $5^{\text {th }}$ & 12 & 4 & 30 & 48 & 94 \\
\hline \multirow[t]{5}{*}{ Price level (in log) } & $1^{\text {st }}$ & 20 & 8 & 32 & 32 & 92 \\
\hline & $2^{\text {nd }}$ & 12 & 17 & 35 & 32 & 96 \\
\hline & $3^{\text {rd }}$ & 9 & 25 & 34 & 29 & 97 \\
\hline & $4^{\text {th }}$ & 7 & 29 & 33 & 27 & 96 \\
\hline & $5^{\text {th }}$ & 7 & 31 & 32 & 27 & 97 \\
\hline \multirow[t]{5}{*}{ Real house price (in $\log$ ) } & $1^{\text {st }}$ & 45 & 32 & 3 & 7 & 87 \\
\hline & $2^{\text {nd }}$ & 42 & 38 & 5 & 7 & 92 \\
\hline & $3^{\text {rd }}$ & 40 & 37 & 6 & 9 & 92 \\
\hline & $4^{\text {th }}$ & 40 & 36 & 6 & 9 & 91 \\
\hline & $5^{\text {th }}$ & 40 & 36 & 6 & 10 & 92 \\
\hline
\end{tabular}


Table 4

Forecast error variance decomposition in robustness test with real total credit as measure of credit (in per cent)

\begin{tabular}{|c|c|c|c|c|c|c|}
\hline & Year & $\begin{array}{c}\text { Loan-to-value } \\
\text { limit shock }\end{array}$ & $\begin{array}{c}\text { Monetary } \\
\text { policy shock }\end{array}$ & $\begin{array}{c}\text { Aggregate } \\
\text { demand shock }\end{array}$ & $\begin{array}{c}\text { Aggregate } \\
\text { Supply shock }\end{array}$ & $\begin{array}{c}\text { Sum of } \\
\text { all shocks }\end{array}$ \\
\hline \multirow[t]{5}{*}{ Real GDP (in log) } & $1^{\mathrm{st}}$ & 11 & 4 & 21 & 55 & 91 \\
\hline & $2^{\text {nd }}$ & 10 & 7 & 25 & 50 & 92 \\
\hline & $3^{\text {rd }}$ & 11 & 7 & 27 & 46 & 91 \\
\hline & $4^{\text {th }}$ & 12 & 7 & 27 & 46 & 92 \\
\hline & $5^{\text {th }}$ & 12 & 7 & 27 & 46 & 92 \\
\hline \multirow[t]{5}{*}{ Price level (in log) } & $1^{\mathrm{st}}$ & 7 & 12 & 20 & 49 & 88 \\
\hline & $2^{\text {nd }}$ & 8 & 15 & 24 & 46 & 93 \\
\hline & $3^{\text {rd }}$ & 8 & 17 & 25 & 43 & 93 \\
\hline & $4^{\text {th }}$ & 9 & 19 & 25 & 41 & 94 \\
\hline & $5^{\text {th }}$ & 10 & 20 & 25 & 39 & 94 \\
\hline \multirow[t]{5}{*}{ Real total credit (in log) } & $1^{\mathrm{st}}$ & 15 & 7 & 26 & 17 & 65 \\
\hline & $2^{\text {nd }}$ & 14 & 11 & 25 & 17 & 67 \\
\hline & $3^{\text {rd }}$ & 16 & 12 & 24 & 18 & 70 \\
\hline & $4^{\text {th }}$ & 16 & 12 & 24 & 19 & 71 \\
\hline & $5^{\text {th }}$ & 16 & 12 & 24 & 19 & 71 \\
\hline
\end{tabular}


Table 5

Forecast error variance decomposition in robustness test with real household credit as measure of credit (in per cent)

\begin{tabular}{|c|c|c|c|c|c|c|}
\hline & Year & $\begin{array}{c}\text { Loan-to-value } \\
\text { limit shock }\end{array}$ & $\begin{array}{c}\text { Monetary } \\
\text { policy shock }\end{array}$ & $\begin{array}{c}\text { Aggregate } \\
\text { demand shock }\end{array}$ & $\begin{array}{c}\text { Aggregate } \\
\text { Supply shock }\end{array}$ & $\begin{array}{c}\text { Sum of } \\
\text { all shocks }\end{array}$ \\
\hline \multirow[t]{5}{*}{ Real GDP (in log) } & $1^{\mathrm{st}}$ & 10 & 3 & 54 & 32 & 99 \\
\hline & $2^{\text {nd }}$ & 13 & 3 & 48 & 35 & 99 \\
\hline & $3^{\text {rd }}$ & 15 & 3 & 49 & 32 & 99 \\
\hline & $4^{\text {th }}$ & 15 & 3 & 49 & 33 & 100 \\
\hline & $5^{\text {th }}$ & 15 & 3 & 49 & 33 & 100 \\
\hline \multirow[t]{5}{*}{ Price level (in log) } & $1^{\mathrm{st}}$ & 1 & 8 & 2 & 58 & 69 \\
\hline & $2^{\text {nd }}$ & 0 & 5 & 3 & 52 & 60 \\
\hline & $3^{\text {rd }}$ & 0 & 4 & 3 & 47 & 54 \\
\hline & $4^{\text {th }}$ & 0 & 4 & 3 & 45 & 52 \\
\hline & $5^{\text {th }}$ & 0 & 4 & 3 & 43 & 50 \\
\hline \multirow[t]{5}{*}{ Real household credit (in log) } & $1^{\mathrm{st}}$ & 17 & 4 & 31 & 47 & 99 \\
\hline & $2^{\text {nd }}$ & 16 & 6 & 27 & 50 & 99 \\
\hline & $3^{\mathrm{rd}}$ & 17 & 7 & 30 & 45 & 99 \\
\hline & $4^{\text {th }}$ & 16 & 6 & 29 & 46 & 97 \\
\hline & $5^{\text {th }}$ & 16 & 6 & 29 & 46 & 97 \\
\hline
\end{tabular}


Table 6

Forecast error variance decomposition in robustness test that include real consumption and real bank credit (in per cent)

\begin{tabular}{|c|c|c|c|c|c|c|}
\hline & Year & $\begin{array}{c}\text { Loan-to-value } \\
\text { limit shock }\end{array}$ & $\begin{array}{c}\text { Monetary } \\
\text { policy shock }\end{array}$ & $\begin{array}{c}\text { Aggregate } \\
\text { demand shock }\end{array}$ & $\begin{array}{c}\text { Aggregate } \\
\text { Supply shock }\end{array}$ & $\begin{array}{c}\text { Sum of } \\
\text { all shocks }\end{array}$ \\
\hline \multirow[t]{5}{*}{ Real consumption (in log) } & $1^{\mathrm{st}}$ & 20 & 11 & 14 & 33 & 78 \\
\hline & $2^{\text {nd }}$ & 19 & 10 & 13 & 38 & 80 \\
\hline & $3^{\text {rd }}$ & 22 & 10 & 12 & 35 & 79 \\
\hline & $4^{\text {th }}$ & 23 & 10 & 12 & 34 & 79 \\
\hline & $5^{\text {th }}$ & 23 & 10 & 13 & 34 & 80 \\
\hline \multirow[t]{5}{*}{ Price level (in log) } & $1^{\mathrm{st}}$ & 3 & 4 & 47 & 26 & 80 \\
\hline & $2^{\text {nd }}$ & 4 & 19 & 41 & 19 & 83 \\
\hline & $3^{\text {rd }}$ & 5 & 32 & 33 & 14 & 84 \\
\hline & $4^{\text {th }}$ & 6 & 41 & 27 & 11 & 85 \\
\hline & $5^{\text {th }}$ & 8 & 46 & 23 & 9 & 86 \\
\hline \multirow[t]{5}{*}{ Real bank credit (in log) } & $1^{\mathrm{st}}$ & 4 & 56 & 12 & 16 & 88 \\
\hline & $2^{\text {nd }}$ & 5 & 53 & 10 & 21 & 89 \\
\hline & $3^{\text {rd }}$ & 11 & 47 & 10 & 19 & 87 \\
\hline & $4^{\text {th }}$ & 14 & 46 & 10 & 18 & 88 \\
\hline & $5^{\text {th }}$ & 14 & 46 & 10 & 18 & 88 \\
\hline
\end{tabular}


Table 7

Forecast error variance decomposition in robustness test that include real investment and real bank credit (in per cent)

\begin{tabular}{|c|c|c|c|c|c|c|}
\hline & Year & $\begin{array}{l}\text { Loan-to-value } \\
\text { limit shock }\end{array}$ & $\begin{array}{c}\text { Monetary } \\
\text { policy shock }\end{array}$ & $\begin{array}{c}\text { Aggregate } \\
\text { demand shock }\end{array}$ & $\begin{array}{c}\text { Aggregate } \\
\text { Supply shock }\end{array}$ & $\begin{array}{c}\text { Sum of } \\
\text { all shocks }\end{array}$ \\
\hline \multirow[t]{5}{*}{ Real investment (in log) } & $1^{\text {st }}$ & 31 & 9 & 17 & 20 & 77 \\
\hline & $2^{\text {nd }}$ & 30 & 7 & 15 & 26 & 78 \\
\hline & $3^{\text {rd }}$ & 32 & 7 & 14 & 25 & 78 \\
\hline & $4^{\text {th }}$ & 32 & 7 & 15 & 25 & 79 \\
\hline & $5^{\text {th }}$ & 32 & 7 & 15 & 25 & 79 \\
\hline \multirow[t]{5}{*}{ Price level (in log) } & $1^{\text {st }}$ & 1 & 2 & 13 & 68 & 84 \\
\hline & $2^{\text {nd }}$ & 6 & 3 & 13 & 51 & 73 \\
\hline & $3^{\mathrm{rd}}$ & 12 & 3 & 13 & 38 & 66 \\
\hline & $4^{\text {th }}$ & 16 & 3 & 13 & 29 & 61 \\
\hline & $5^{\text {th }}$ & 18 & 3 & 24 & 14 & 59 \\
\hline \multirow[t]{5}{*}{ Real bank credit (in log) } & $1^{\text {st }}$ & 45 & 12 & 3 & 38 & 98 \\
\hline & $2^{\text {nd }}$ & 37 & 10 & 2 & 44 & 93 \\
\hline & $3^{\mathrm{rd}}$ & 35 & 10 & 3 & 42 & 90 \\
\hline & $4^{\text {th }}$ & 34 & 9 & 5 & 41 & 89 \\
\hline & $5^{\text {th }}$ & 33 & 9 & 5 & 40 & 87 \\
\hline
\end{tabular}


Table 8

Forecast error variance decomposition in robustness test that include real bank credit and inflation (in per cent)

\begin{tabular}{|c|c|c|c|c|c|c|}
\hline & Year & $\begin{array}{c}\text { Loan-to-value } \\
\text { limit shock }\end{array}$ & $\begin{array}{c}\text { Monetary } \\
\text { policy shock }\end{array}$ & $\begin{array}{c}\text { Aggregate } \\
\text { demand shock }\end{array}$ & $\begin{array}{c}\text { Aggregate } \\
\text { Supply shock }\end{array}$ & $\begin{array}{c}\text { Sum of } \\
\text { all shocks }\end{array}$ \\
\hline \multirow[t]{5}{*}{ Real GDP (in log) } & $1^{\text {st }}$ & 31 & 10 & 5 & 36 & 82 \\
\hline & $2^{\text {nd }}$ & 19 & 6 & 10 & 33 & 68 \\
\hline & $3^{\mathrm{rd}}$ & 17 & 6 & 11 & 30 & 64 \\
\hline & $4^{\text {th }}$ & 17 & 7 & 10 & 29 & 63 \\
\hline & $5^{\text {th }}$ & 17 & 7 & 10 & 29 & 63 \\
\hline \multirow[t]{5}{*}{ Inflation } & $1^{\text {st }}$ & 29 & 1 & 23 & 15 & 68 \\
\hline & $2^{\text {nd }}$ & 24 & 3 & 27 & 11 & 65 \\
\hline & $3^{\text {rd }}$ & 24 & 4 & 26 & 11 & 65 \\
\hline & $4^{\text {th }}$ & 24 & 5 & 26 & 11 & 66 \\
\hline & $5^{\text {th }}$ & 24 & 5 & 25 & 11 & 65 \\
\hline \multirow[t]{5}{*}{ Real bank credit (in log) } & $1^{\text {st }}$ & 32 & 11 & 28 & 24 & 95 \\
\hline & $2^{\text {nd }}$ & 23 & 8 & 16 & 26 & 73 \\
\hline & $3^{\mathrm{rd}}$ & 19 & 8 & 14 & 24 & 65 \\
\hline & $4^{\text {th }}$ & 18 & 8 & 13 & 23 & 62 \\
\hline & $5^{\text {th }}$ & 18 & 9 & 12 & 23 & 62 \\
\hline
\end{tabular}


Table 9

Forecast error variance decomposition in robustness test that considers alternative identification restriction and includes real bank credit (in per cent)

\begin{tabular}{|c|c|c|c|c|c|c|}
\hline & Year & $\begin{array}{c}\text { Loan-to-value } \\
\text { limit shock }\end{array}$ & $\begin{array}{c}\text { Monetary } \\
\text { policy shock }\end{array}$ & $\begin{array}{c}\text { Aggregate } \\
\text { demand shock }\end{array}$ & $\begin{array}{c}\text { Aggregate } \\
\text { Supply shock }\end{array}$ & $\begin{array}{c}\text { Sum of } \\
\text { all shocks }\end{array}$ \\
\hline \multirow[t]{5}{*}{ Real GDP (in log) } & $1^{\text {st }}$ & 5 & 11 & 35 & 37 & 88 \\
\hline & $2^{\text {nd }}$ & 5 & 10 & 38 & 33 & 86 \\
\hline & $3^{\mathrm{rd}}$ & 8 & 9 & 39 & 31 & 87 \\
\hline & $4^{\text {th }}$ & 9 & 9 & 38 & 32 & 88 \\
\hline & $5^{\text {th }}$ & 8 & 9 & 38 & 31 & 86 \\
\hline \multirow[t]{5}{*}{ Price level (in log) } & $1^{\text {st }}$ & 23 & 11 & 13 & 19 & 66 \\
\hline & $2^{\text {nd }}$ & 16 & 26 & 14 & 22 & 78 \\
\hline & $3^{\text {rd }}$ & 11 & 36 & 13 & 22 & 82 \\
\hline & $4^{\text {th }}$ & 9 & 43 & 12 & 22 & 86 \\
\hline & $5^{\text {th }}$ & 8 & 48 & 12 & 22 & 90 \\
\hline \multirow[t]{5}{*}{ Real bank credit (in log) } & $1^{\text {st }}$ & 9 & 47 & 33 & 4 & 93 \\
\hline & $2^{\text {nd }}$ & 7 & 48 & 28 & 3 & 86 \\
\hline & $3^{\mathrm{rd}}$ & 8 & 46 & 28 & 5 & 87 \\
\hline & $4^{\text {th }}$ & 8 & 45 & 27 & 7 & 87 \\
\hline & $5^{\text {th }}$ & 8 & 45 & 26 & 7 & 86 \\
\hline
\end{tabular}


Table 10

Forecast error variance decomposition in robustness test that include real consumption and real house price (in per cent)

\begin{tabular}{|c|c|c|c|c|c|c|}
\hline & Year & $\begin{array}{l}\text { Loan-to-value } \\
\text { limit shock }\end{array}$ & $\begin{array}{c}\text { Monetary } \\
\text { policy shock }\end{array}$ & $\begin{array}{c}\text { Aggregate } \\
\text { demand shock }\end{array}$ & $\begin{array}{c}\text { Aggregate } \\
\text { Supply shock }\end{array}$ & $\begin{array}{c}\text { Sum of } \\
\text { all shocks }\end{array}$ \\
\hline \multirow[t]{5}{*}{ Real consumption (in log) } & $1^{\text {st }}$ & 39 & 1 & 19 & 38 & 97 \\
\hline & $2^{\text {nd }}$ & 35 & 1 & 16 & 45 & 97 \\
\hline & $3^{\text {rd }}$ & 36 & 1 & 17 & 42 & 96 \\
\hline & $4^{\text {th }}$ & 36 & 1 & 16 & 43 & 96 \\
\hline & $5^{\text {th }}$ & 36 & 2 & 16 & 42 & 96 \\
\hline \multirow[t]{5}{*}{ Price level (in log) } & $1^{\text {st }}$ & 12 & 0 & 36 & 41 & 89 \\
\hline & $2^{\text {nd }}$ & 7 & 1 & 42 & 43 & 93 \\
\hline & $3^{\text {rd }}$ & 6 & 3 & 44 & 42 & 95 \\
\hline & $4^{\text {th }}$ & 5 & 4 & 45 & 42 & 96 \\
\hline & $5^{\text {th }}$ & 5 & 4 & 45 & 42 & 96 \\
\hline \multirow[t]{5}{*}{ Real house price (in log) } & $1^{\mathrm{st}}$ & 22 & 46 & 3 & 12 & 83 \\
\hline & $2^{\text {nd }}$ & 27 & 22 & 4 & 10 & 63 \\
\hline & $3^{\text {rd }}$ & 27 & 21 & 4 & 11 & 63 \\
\hline & $4^{\text {th }}$ & 28 & 21 & 4 & 11 & 64 \\
\hline & $5^{\text {th }}$ & 28 & 21 & 4 & 12 & 65 \\
\hline
\end{tabular}


Table 11

Forecast error variance decomposition in robustness test that include real investment and real house price (in per cent)

\begin{tabular}{|c|c|c|c|c|c|c|}
\hline & Year & $\begin{array}{c}\text { Loan-to-value } \\
\text { limit shock }\end{array}$ & $\begin{array}{c}\text { Monetary } \\
\text { policy shock }\end{array}$ & $\begin{array}{c}\text { Aggregate } \\
\text { demand shock }\end{array}$ & $\begin{array}{c}\text { Aggregate } \\
\text { Supply shock }\end{array}$ & $\begin{array}{c}\text { Sum of } \\
\text { all shocks }\end{array}$ \\
\hline \multirow[t]{5}{*}{ Real investment (in log) } & $1^{\text {st }}$ & 7 & 9 & 65 & 11 & 92 \\
\hline & $2^{\text {nd }}$ & 9 & 8 & 59 & 15 & 91 \\
\hline & $3^{\text {rd }}$ & 9 & 7 & 60 & 15 & 91 \\
\hline & $4^{\text {th }}$ & 9 & 7 & 59 & 15 & 90 \\
\hline & $5^{\text {th }}$ & 9 & 7 & 59 & 15 & 90 \\
\hline \multirow[t]{5}{*}{ Price level (in log) } & $1^{\text {st }}$ & 4 & 51 & 6 & 35 & 96 \\
\hline & $2^{\text {nd }}$ & 9 & 51 & 4 & 27 & 91 \\
\hline & $3^{\text {rd }}$ & 12 & 51 & 4 & 23 & 90 \\
\hline & $4^{\text {th }}$ & 14 & 52 & 3 & 21 & 90 \\
\hline & $5^{\text {th }}$ & 15 & 53 & 3 & 20 & 91 \\
\hline \multirow[t]{5}{*}{ Real house price (in log) } & $1^{\text {st }}$ & 33 & 4 & 2 & 6 & 45 \\
\hline & $2^{\text {nd }}$ & 39 & 8 & 2 & 5 & 54 \\
\hline & $3^{\text {rd }}$ & 38 & 8 & 3 & 5 & 54 \\
\hline & $4^{\text {th }}$ & 37 & 8 & 4 & 5 & 54 \\
\hline & $5^{\text {th }}$ & 37 & 8 & 4 & 5 & 54 \\
\hline
\end{tabular}


Table 12

Forecast error variance decomposition in robustness test that include real house price and inflation (in per cent)

\begin{tabular}{|c|c|c|c|c|c|c|}
\hline & Year & $\begin{array}{l}\text { Loan-to-value } \\
\text { limit shock }\end{array}$ & $\begin{array}{c}\text { Monetary } \\
\text { policy shock }\end{array}$ & $\begin{array}{c}\text { Aggregate } \\
\text { demand shock }\end{array}$ & $\begin{array}{c}\text { Aggregate } \\
\text { Supply shock }\end{array}$ & $\begin{array}{c}\text { Sum of } \\
\text { all shocks }\end{array}$ \\
\hline \multirow[t]{5}{*}{ Real GDP (in log) } & $1^{\mathrm{st}}$ & 10 & 31 & 8 & 10 & 59 \\
\hline & $2^{\text {nd }}$ & 15 & 21 & 28 & 8 & 72 \\
\hline & $3^{\text {rd }}$ & 14 & 20 & 33 & 8 & 75 \\
\hline & $4^{\text {th }}$ & 15 & 19 & 33 & 8 & 75 \\
\hline & $5^{\text {th }}$ & 15 & 19 & 34 & 8 & 76 \\
\hline \multirow[t]{5}{*}{ Inflation } & $1^{\text {st }}$ & 4 & 1 & 56 & 13 & 74 \\
\hline & $2^{\text {nd }}$ & 7 & 1 & 55 & 18 & 81 \\
\hline & $3^{\text {rd }}$ & 6 & 2 & 54 & 18 & 80 \\
\hline & $4^{\text {th }}$ & 7 & 2 & 54 & 19 & 82 \\
\hline & $5^{\text {th }}$ & 7 & 2 & 54 & 19 & 82 \\
\hline \multirow[t]{5}{*}{ Real house price (in log) } & $1^{\text {st }}$ & 69 & 2 & 14 & 9 & 94 \\
\hline & $2^{\text {nd }}$ & 65 & 1 & 16 & 8 & 90 \\
\hline & $3^{\text {rd }}$ & 55 & 2 & 24 & 11 & 92 \\
\hline & $4^{\text {th }}$ & 50 & 2 & 27 & 12 & 91 \\
\hline & $5^{\text {th }}$ & 48 & 3 & 28 & 12 & 91 \\
\hline
\end{tabular}

